Prepared in cooperation with the Federal Emergency Management Agency

\title{
Flood of May 2006 in New Hampshire
}

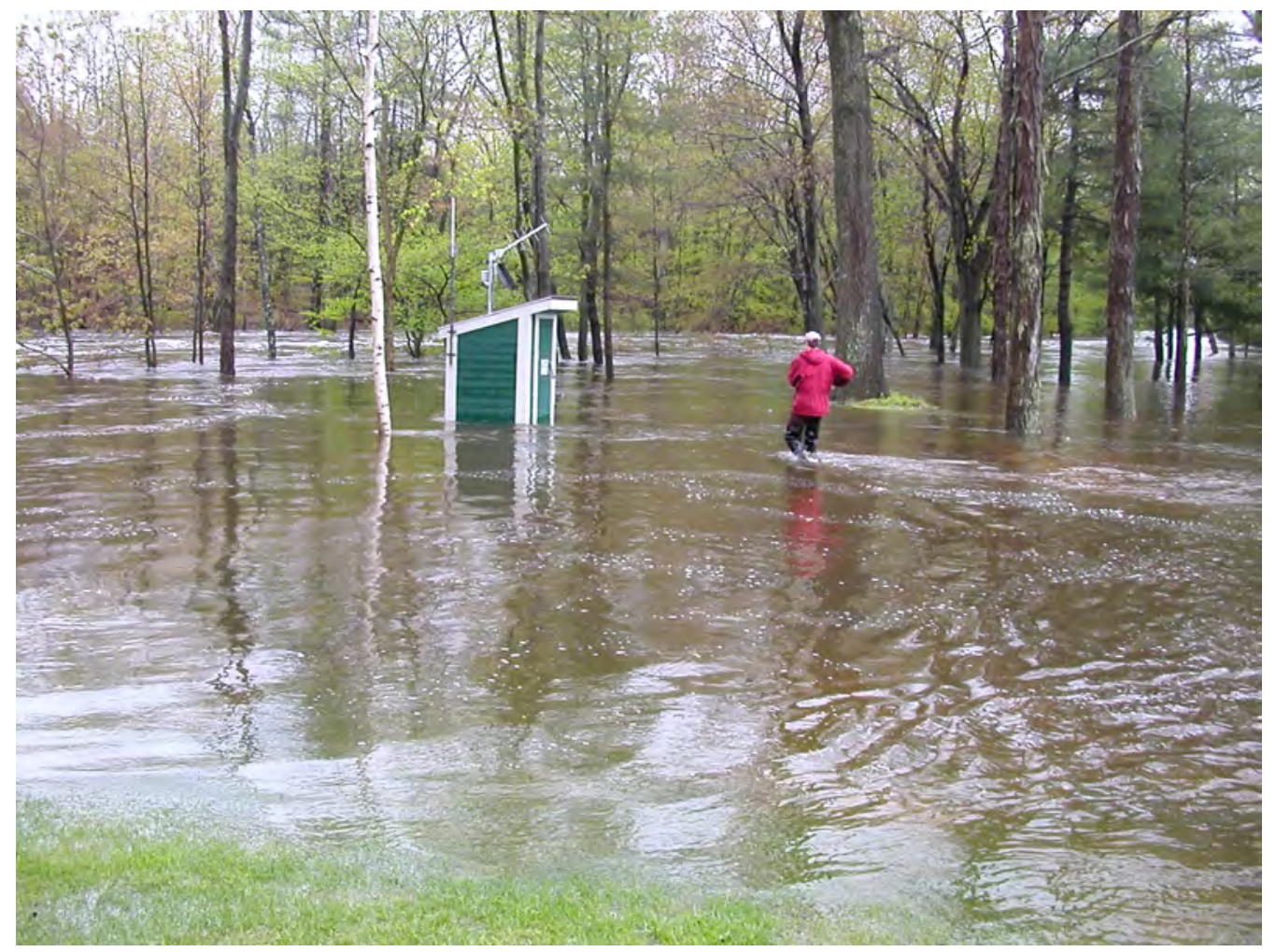

Open-File Report 2007-1122

U.S. Department of the Interior

U.S. Geological Survey 
Cover. Photograph showing Cocheco River near Rochester, New Hampshire streamgage during the flood of May 2006. 


\section{Flood of May 2006 in New Hampshire}

By Scott A. Olson

Prepared in cooperation with the Federal Emergency Management Agency

Open-File Report 2007-1122

U.S. Department of the Interior

U.S. Geological Survey 


\title{
U.S. Department of the Interior DIRK KEMPTHORNE, Secretary
}

\author{
U.S. Geological Survey \\ Mark D. Myers, Director
}

U.S. Geological Survey, Reston, Virginia: 2007

For product and ordering information:

World Wide Web: http://www.usgs.gov/pubprod

Telephone: 1-888-ASK-USGS

For more information on the USGS - the Federal source for science about the Earth, its natural and living resources, natural hazards, and the environment:

World Wide Web: http://www.usgs.gov

Telephone: 1-888-ASK-USGS

Any use of trade, product, or firm names is for descriptive purposes only and does not imply endorsement by the U.S. Government.

Although this report is in the public domain, permission must be secured from the individual copyright owners to reproduce any copyrighted materials contained within this report.

Suggested citation:

Olson, S.A., 2007, Flood of May 2006 in New Hampshire: U.S. Geological Survey Open-File Report 2007-1122, 32 p. 


\section{Contents}

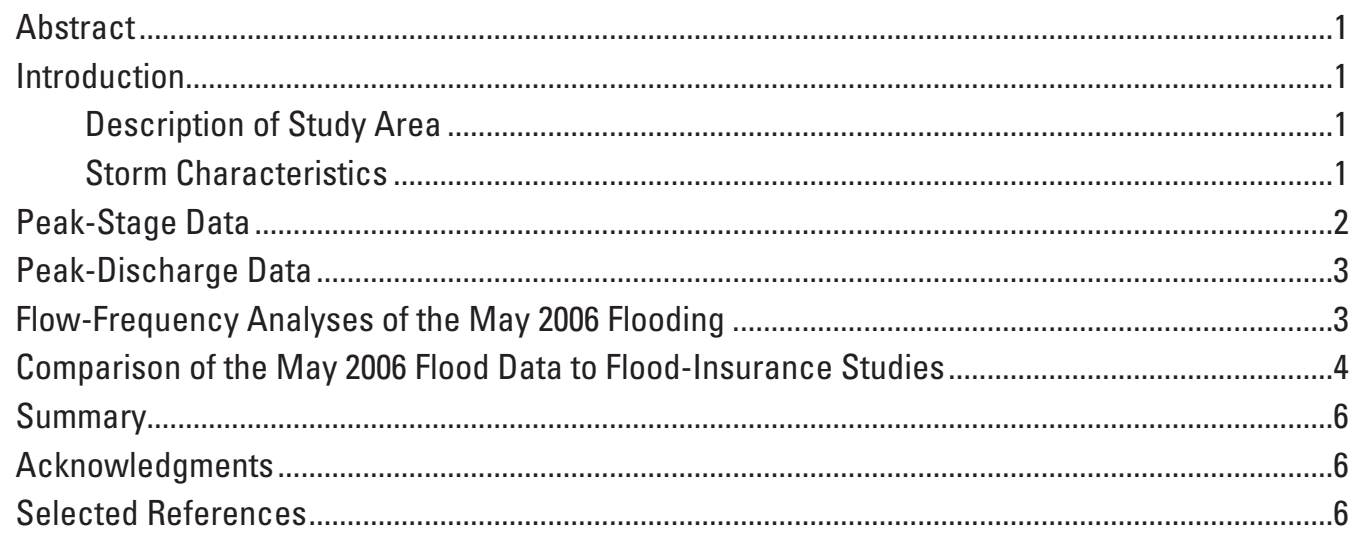

\section{Figures}

1. Screenshot showing the 7-day precipitation totals ending on May 18, 2006, northeastern United States.

2-3. Maps showing:

2A. Location of streamgages having peak stage and discharge data for the May 2006 flooding in Hillsborough County, New Hampshire..

2B. Location of streamgages having peak stage and discharge data for the May 2006 flooding in Rockingham County, New Hampshire

2C. Location of streamgages having peak stage and discharge data for the May 2006 flooding in Merrimack County, New Hampshire..

2D. Location of streamgages having peak stage and discharge data for the May 2006 flooding in Belknap County, New Hampshire.

2E. Location of streamgages having peak stage and discharge data for the May 2006 flooding in Strafford County, New Hampshire...

2F. Location of streamgages having peak stage and discharge data for the May 2006 flooding in Grafton County, New Hampshire.

2G. Location of streamgages having peak stage and discharge data for the May 2006 flooding in Carroll County, New Hampshire

3. Recurrence intervals of the May 2006 flood at streamgages in Hillsborough, Rockingham, Merrimack, Belknap, Strafford, Grafton, and Carroll Counties in central and southern New Hampshire. 


\section{Tables}

1. Description of streamgages used to characterize the floods of May 2006 in central and southern New Hampshire

2. Peak-stage data and peak-discharge data for the flooding in May 2006 at 65 streamgages in central and southern New Hampshire

3. Flow-frequency data and recurrence interval estimates of the May 2006 flood for 65 streamgages in central and southern New Hampshire.

4. Relation of computed May 2006 flood discharge and stage data to flood-insurance study data for selected streamgages in central and southern New Hampshire

. .30

\section{Conversion Factors and Datums}

\begin{tabular}{lcl}
\hline & Multiply & \multicolumn{1}{c}{ By obtain } \\
\hline inch (in.) & Length & \\
inch (in.) & 2.54 & centimeter $(\mathrm{cm})$ \\
foot (ft) & 25.4 & millimeter $(\mathrm{mm})$ \\
mile (mi) & 0.3048 & meter $(\mathrm{m})$ \\
& 1.609 & kilometer $(\mathrm{km})$ \\
\hline square mile $\left(\mathrm{mi}^{2}\right)$ & Area & \\
\hline & 2.590 & square kilometer $\left(\mathrm{km}^{2}\right)$ \\
\hline cubic foot per second $\left(\mathrm{ft}{ }^{3} / \mathrm{s}\right)$ & Flow rate & \\
\hline
\end{tabular}

Horizontal coordinate information is referenced to the North American Datum of 1927 (NAD 27).

Vertical coordinate information is referenced to the National Geodetic Vertical Datum of 1929 (NGVD 29) and North American Vertical Datum of 1988 (NAVD 88). 


\title{
Flood of May 2006 in New Hampshire
}

\author{
By Scott A. Olson
}

\section{Abstract}

From May 13-17, 2006, central and southern New Hampshire experienced severe flooding caused by as much as 14 inches of rainfall in the region. As a result of the flood damage, a presidential disaster declaration was made on May 25, 2006, for seven counties-Rockingham, Hillsborough, Strafford, Merrimack, Belknap, Carroll, and Grafton. Following the flooding, the U.S. Geological Survey, in a cooperative investigation with the Federal Emergency Management Agency, determined the peak stages, peak discharges, and recurrence-interval estimates of the May 2006 flood at 65 streamgages in the counties where the disaster declaration was made. Data from flood-insurance studies published by the Federal Emergency Management Agency also were compiled for each streamgage location for comparison purposes.

The peak discharges during the May 2006 flood were the largest ever recorded at 14 long-term (more than 10 years of record) streamgages in New Hampshire. In addition, peak discharges equaled or exceeded a 100-year recurrence interval at 14 streamgages and equaled or exceeded a 50-year recurrence interval at 22 streamgages. The most severe flooding occurred in Rockingham, Strafford, Merrimack, and eastern and northern Hillsborough Counties.

\section{Introduction}

Major flooding in central and southern New Hampshire from May 13-17, 2006, resulted in significant damage to public and personal property. Roads were damaged and numerous residential areas were evacuated for several days. As a result of the widespread damage caused by the flooding, President George W. Bush declared a disaster area in seven counties in New Hampshire on May 25, 2006. In response to this declaration, the U.S. Geological Survey (USGS), in cooperation with the Federal Emergency Management Agency (FEMA), measured or computed flood data at 65 streamgages within the disaster declaration area.

This report documents the flood of May of 2006 by presenting the flood data collected at the streamgages (48 active and 17 discontinued) in central and southern New Hampshire. The flood data include peak-stage data, peak-discharge data, flow-frequency curves, and estimates of flood recurrence intervals at each streamgage. In addition, data were compiled from FEMA flood-insurance studies for comparison purposes. The active streamgages included 37 operated by the USGS, 8 operated by the New Hampshire Department of Environmental Services (NHDES), 2 operated by the U.S. Army Corps of Engineers (USACE), and 1 operated privately. All 17 discontinued streamgages were those that had been operated by the USGS. A description of each streamgage location included in this investigation is listed in table 1 (in back of report). All data contained in this report should be considered provisional and, therefore, subject to revision.

\section{Description of Study Area}

The New Hampshire counties declared in the disaster comprise a land area of 5,923 $\mathrm{mi}^{2}$ in the northeastern United States. Land altitudes range from sea level along the coast to greater than 4,000 ft NAVD 88 in the north-central part of New Hampshire. The climate of New Hampshire is humid. Precipitation is distributed fairly evenly across the state and averages about 43 in. per year except in regions of high elevation, which can receive an additional 10 to 15 in. of precipitation annually. The statewide average precipitation for the month of May is approximately 3.75 in. (Northeast Regional Climate Center, 2006).

\section{Storm Characteristics}

The storms of May 11-15, 2006, produced nearly 14 in. of rainfall in the coastal regions of New Hampshire (National Oceanic and Atmospheric Administration, 2006a) and up to 11 in. in the south-central part of the state (National Oceanic and Atmospheric Administration, 2006b). The rainfall began on May 11, 2006. As an on-shore flow developed, copious amounts of moisture were drawn in from the Atlantic Ocean. The rainfall continued for more than 100 hours with the heaviest rainfall occurring on May 13 and 14, 2006. The rainfall amounts decreased abruptly in the northern and western regions of the state (fig. 1). In addition to the precipitation amounts of May 11-15, 2006, being exceptional, the month of May 2006 was the second wettest May in New Hampshire on record (National Oceanic and Atmospheric Administration, 2006c) and the wettest in Concord, New 


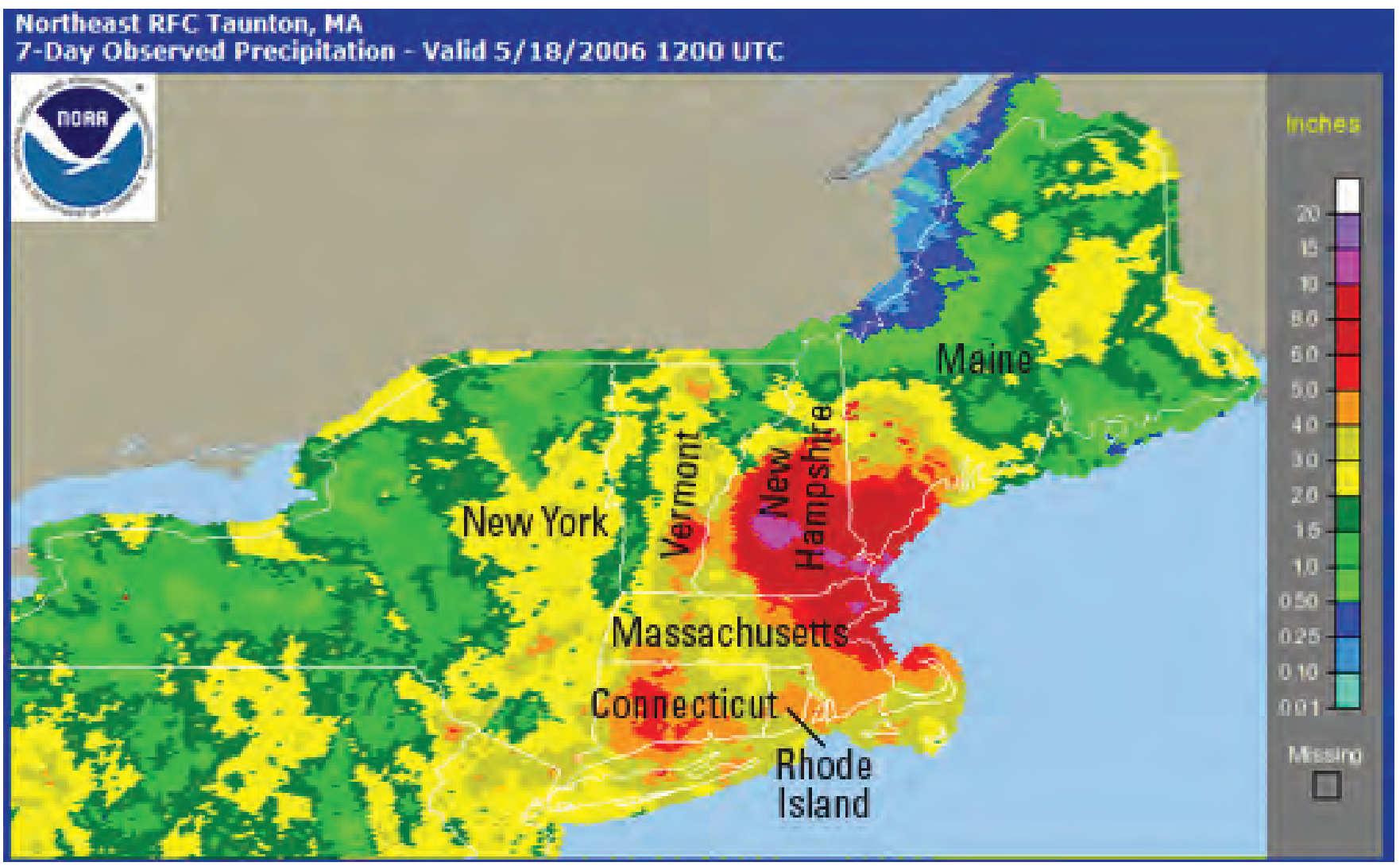

Figure 1. The 7-day precipitation totals ending on May 18, 2006, northeastern United States. (From Northeast River Forecast Center, 2006.)

Hampshire since 1868 (Erick Boehmler, Northeast River Forecast Center, written commun., November 3, 2006).

The amount of precipitation occurring May 11-15, 2006, was similar to the amount of precipitation that occurred October 20-22, 1996, when as much as 13 in. of precipitation fell across southeastern New Hampshire (National Oceanic and Atmospheric Administration, 1996). The October 1996 precipitation resulted in discharges that were the maximum for the period of record at several streamgages in southeastern New Hampshire. The peak discharge of October 21, 1996, remains the peak discharge of record at the Oyster River near Durham, New Hampshire, streamgage. The primary difference between the events of May 2006 and October 1996 was the wetter antecedent ground conditions in May of 2006 (National Oceanic and Atmospheric Administration, 2006b) resulting in greater discharges during May of 2006 at many streamgages.

\section{Peak-Stage Data}

At active streamgages operated by the USGS, peak stages were retrieved directly from the stage data recorded at the streamgage, along with the precise date and time of the peak stage. At active streamgages not operated by the USGS, the peak stage with date and time was provided by the opera- tor. All peak stage data from streamgages were rated excellent, which means that measurements are considered to be within $0.05 \mathrm{ft}$ of the actual peak water surface.

At discontinued streamgages, USGS personnel identified and flagged the May 2006 high-water marks near the streamgage. The high-water marks typically consisted of debris lines, wash lines or mud lines left behind by the peak water elevation during the flood event. The flagged highwater marks were rated for accuracy. This accuracy rating is subjective and is based upon the type of high-water mark and the abundance of other confirming marks in the immediate vicinity (Benson and Dalrymple, 1967). The accuracy of the marks are defined as follows: A high-water mark having (1) an excellent rating is thought to be within $0.05 \mathrm{ft}$ of the actual water surface, (2) a good rating is expected to have been within $0.1 \mathrm{ft}$, (3) a fair rating is within $0.2 \mathrm{ft}$, and (4) a poor rating may be greater then $0.2 \mathrm{ft}$ from the true peak water surface.

The high-water marks at the discontinued streamgages were then referenced to the datum of the streamgage using closed level-loop surveying techniques. The streamgage datum is the local base elevation that was used in developing the stage-discharge relation when the streamgage was active. As the high-water marks were referenced to the streamgage datum, the marks represented the peak stages of the flood- 
ing at the discontinued streamgage. The estimated date of the peak stages at discontinued streamgages was estimated from observations by residents living near the streamgage or from peak-stage hydrographs from active streamgages in the same or adjacent watersheds.

If a FEMA flood-insurance study containing flood-water elevations was available for the location of the discontinued or active streamgage, the peak stage at the streamgage was referenced to the National Geodetic Vertical Datum of 1929 (NGVD 29) and the North American Vertical Datum of 1988 (NAVD 88) using closed level-loop surveying techniques. Referencing the peak stage to NGVD 29 and NAVD 88 allows the high-water mark to be compared to the existing FEMA flood-insurance study data at the streamgage location. Other selected streamgages also were referenced to NGVD 29 and NAVD 88 regardless of the availability of a flood-insurance study at the streamgage location. The peak-stage data for all sites included in this investigation are shown in table 2 (in back of report). The location of each streamgage is shown, by county, in figures $2 \mathrm{~A}-2 \mathrm{G}$ (in back of report).

\section{Peak-Discharge Data}

Peak discharges for most streamgages were determined by applying the peak stage to the most current stage-discharge relation developed for the streamgage. At discontinued streamgages there is the possibility that the stage-discharge relation has changed during the years that the site has been inactive. Each of the discontinued streamgages, however, is at a site having a stable channel or control, and the most recent stage-discharge relation available for the site will provide reasonable results.

There were four exceptions to using the stage-discharge relation for determining the peak discharge of the May 2006 flood:

1. At 12 streamgages (table 2, footnote $b$ ), the current stagedischarge relation was undeveloped for the unusually large peak stage. In such cases, the stage-discharge relation was graphically extended to the peak stage using the trend of the upper end of the stage-discharge relation. The error introduced to the peak-discharge value is unknown when extending the stage-discharge relation without manually measured discharges.

2. At three streamgages (table 2, footnote d), backwater from hydraulic conditions in the channel downstream of the streamgage prevented the use of the stage-discharge relation to determine the peak discharge from the peak stage. The peak discharges at these streamgages are unknown. All three of these streamgages had been discontinued.

3. At active streamgage 01100561, Spicket River near Methuen, MA (table 2, footnote $\mathrm{n}$ ), there was a variable backwater condition during the May 2006 flooding. At the time of this publication, a peak discharge had not been computed; however, a discharge measurement of $2,260 \mathrm{ft}^{3} / \mathrm{s}$ was made at a stage of $11.91 \mathrm{ft}$. The peak stage of the May 2006 flood was $12.15 \mathrm{ft}$.

4. At discontinued streamgage 01091000 , South Branch Piscataquog River near Goffstown, NH (table 2, footnote 1), the gage house and datum reference marks were destroyed during the construction of a new bridge prior to the May 2006 flood. Because the reference marks were destroyed, it was not possible to tie the high-water marks flagged at the site to the streamgage datum. Without high-water marks tied to the streamgage datum, the stage-discharge relation for the streamgage could not be used. The bridge, however, provided sufficient river constriction, and enough high-water marks were available upstream and downstream of the bridge to allow a discharge estimate to be made at the bridge using indirect techniques (Matthai, 1967). At this site, the high-water marks downstream of the bridge, the bridge opening, and channel and floodplain cross sections upstream and downstream of the bridge were surveyed and input into the U.S. Army Corps of Engineers (2006a) HEC-RAS program. Discharges were iteratively selected and input into the HEC-RAS program so that the resulting water-surface elevation output from the program matched the high-water marks surveyed upstream of the bridge. This hydraulic model calibrated to the high-water marks resulted in a discharge of $7,180 \mathrm{ft}^{3} / \mathrm{s}$.

At 14 long-term (more than 10 years of record) streamgages, the peak discharge from the May 2006 flood was the maximum discharge for the period of record. These 14 streamgages are listed in table 2 with discharges with footnote "c" and include 2 streamgages with very long periods of record-Lamprey River near Newmarket (active since 1934) and Warner River at Davisville (period of record from 1940 to 1978 and 1999 to the present). The peak-discharge data for all sites included in this investigation are given in table 2.

\section{Flow-Frequency Analyses of the May 2006 Flooding}

Flow-frequency curves were determined for all 65 streamgages included in this investigation. For 37 of the 65 streamgages, the guidelines in Bulletin 17B (U.S. Interagency Advisory Committee on Water Data, 1982) were used to determine flow-frequency curves. Bulletin 17B recommends the use of a log-Pearson Type III distribution for estimating flow frequency and provides procedures for weighting station skews, historical peaks, and detecting and treating outliers and trends. Software developed by the USGS to analyze peak-flow frequency (PeakFQ) was used for these computations (U.S. Geological Survey, 2006a). The peak-flow data used as input to the PeakFQ program were retrieved from the National Water Information System (U.S. Geological Survey, 2006b). When computing the flow-frequency curves, if peak 
discharges at a streamgage were affected by regulation, the station skew-without weighting from the generalized skew as described in Bulletin 17B-was used for computing the frequency curve. If the May 2006 peak discharge was the annual peak for the 2006 water year, it was added to the peak-flow data prior to computing the frequency curves.

For 11 of the 65 streamgages, flood-control structures operated by the USACE are present in the basin. Flowfrequency data for 8 of these 11 streamgages were obtained from frequency curves developed by the USACE and published in FEMA flood-insurance studies (table 3, in back of report; footnote a). At 3 of the 11 streamgages, the flowfrequency curve published in the FEMA flood-insurance study was not developed by the USACE, and the flow-frequency curve was re-computed for this study following the Bulletin 17B guidelines and incorporating peak-flow data since the flood-control structures were constructed.

At 16 of the 65 streamgages in this investigation, the record length was insufficient-less than 10 years - for a flow-frequency analysis. (Bulletin 17B recommends at least 10 years.) At these sites, the flow-frequency curves were computed using the regression equations for estimating flow frequency developed by LeBlanc (1978). The resulting frequency curves were not adjusted for urbanization or regulation.

At one site, station 01080000, Lake Winnipesaukee at Weirs Beach, only stage data are available. The frequency data for this site were obtained from the flood-insurance study for the city of Laconia (Federal Emergency Management Agency, 1980a).

Results of the flow-frequency analyses are shown in table 3. The recurrence interval of the May 2006 peak flow at each streamgage was determined using the frequency analysis results. Peak discharge equaled or exceeded a 50-year flood at 22 streamgages; 20 of these were located in Rockingham, Merrimack, Strafford or northern and eastern Hillsborough Counties (fig. 3). Peak discharge equaled or exceeded a 100 -year flood at 14 streamgages:

1. North River above NH125, near Lee;

2. Lamprey River near Newmarket;

3. Exeter River at Haigh Road, near Brentwood;

4. Dudley Brook near Exeter;

5. Mill Brook near NH108, at Stratham;

6. Winnicut River at Greenland, near Portsmouth;

7. Berrys Brook at Sagamore Road, near Portsmouth;

8. Little River at Woodland Road, near Hampton;

9. Poorfarm Brook near Gilford;

10. Warner River at Davisville;

11. Soucook River near Concord;
12. Soucook River at Pembroke Road, near Concord;

13. South Branch Piscataquog River near Goffstown; and

14. Merrimack River near Goffs Falls, below Manchester.

\section{Comparison of the May 2006 Flood Data to Flood-Insurance Studies}

FEMA flood-insurance studies provide communities with discharges and water-surface-elevation profiles for the 10-, 50-, 100-, and 500-year floods for many water courses around which development has or is expected to occur. These data are used for planning purposes and for setting flood-insurance rates for structures within communities participating in the National Flood-Insurance Program. For streamgage locations included within a flood-insurance study, discharges and peak water-surface elevations (stage) were compiled from the appropriate study and are given in table 4 (in back of report). Discharges were obtained from the Summary of Discharges table for the reach that incorporated the streamgage location, and the peak water-surface elevations were extracted from the water-surface-elevation profiles. In cases where the streamgage location was not identified on the water-surfaceelevation profiles, interpretation of the streamgage location was required.

The compiled flood-insurance study data are shown along with the peak stage and peak discharge for the May 2006 flood in table 4. The flow-frequency data obtained from the flood-insurance studies (table 4) often differ from the flow-frequency data determined for this investigation (table 3), because the methods used for determining the frequency curves and the availability of data for developing the frequency curves may be different.

In addition, the data in table 4 indicates that the watersurface-elevation profiles for some communities may need to be updated. For instance, at streamgage 01091500, Piscataquog River near Goffstown, the peak discharge in May 2006 was $10,100 \mathrm{ft}^{3} / \mathrm{s}$. The recurrence interval for this discharge, as reported in the Goffstown flood-insurance study (Federal Emergency Management Agency, 1978b) is between 50 and 100 years. One would expect the peak stage in May 2006 to fall between the 50- and 100-year water-surface-elevation profiles at this location; however, the peak stage for the May 2006 flood was $187.20 \mathrm{ft}$ NGVD 29, which is greater than the 100-year water-surface-elevation reported in the Goffstown flood-insurance study. There are 14 streamgage sites at which the observed peak discharge of the May 2006 flood is bracketed by different recurrence intervals than the recurrence intervals that bracket the observed stage or watersurface elevation (table 4). These discrepancies could be due to changes to the river channel, changes in land use, or changes to other physical data used in the hydraulic modeling performed for the study. 


\section{EXPLANATION}

$\begin{array}{ll} & \text { Lake } \\ & \text { River } \\ ---- & \text { County boundary }\end{array}$

Recurrence interval of peak discharge at streamgages, May 2006.

$\triangle$ Less than 10-year flood

$\triangle$ 10- to less than 50-year flood

$\triangle \quad 50$ - to less than 100-year flood

$\Delta$ Equal to or greater than 100-year flood

$\Delta$ Recurrence interval unknown

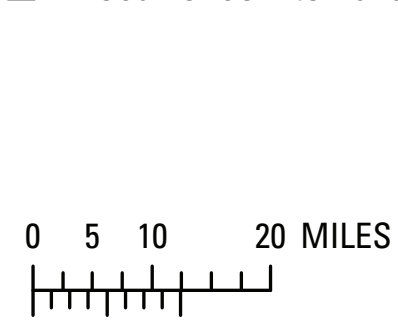

$0 \quad 510 \quad 20$ KILOMETERS

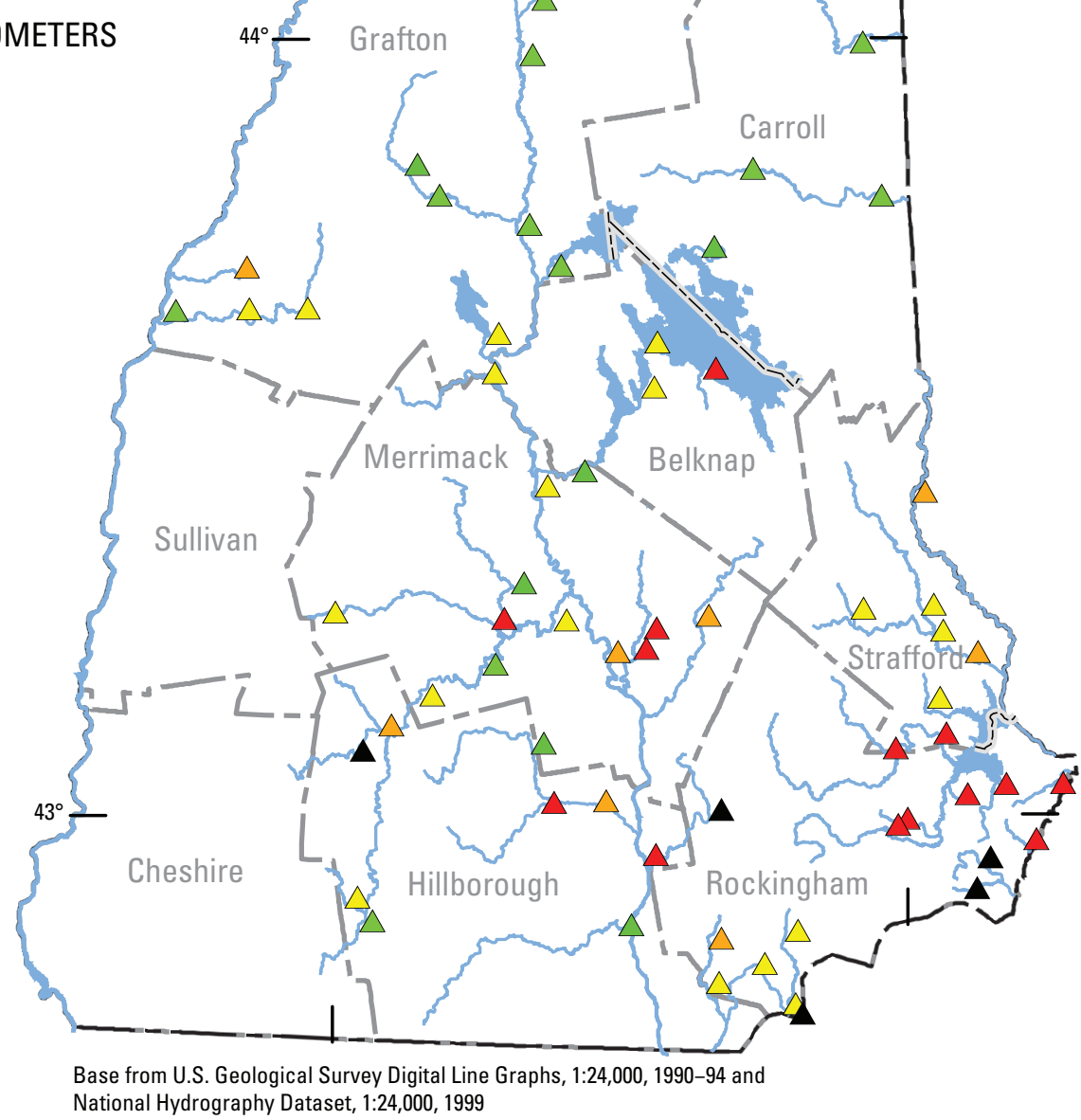

Figure 3. Recurrence intervals of the May 2006 flood at streamgages in Hillsborough, Rockingham, Merrimack, Belknap, Strafford, Grafton, and Carroll Counties in central and southern New Hampshire. 


\section{Summary}

From May 13-17, 2006, central and southern New Hampshire experienced severe flooding caused by as much as $14 \mathrm{in}$. of rainfall in the region, and seven counties were declared a disaster area. The U.S. Geological Survey, in a cooperative investigation with the Federal Emergency Management Agency (FEMA), measured or computed flood data at 65 streamgages in the disaster area. These data include peak stages, peak discharges, and recurrence interval estimates for the May 2006 flooding and data compiled from FEMA floodinsurance studies for comparison purposes.

At 14 long-term (more than 10 years of record) streamgages, the peak discharge in May 2006 was the maximum discharge for the period of record. These streamgages include the Lamprey River near Newmarket (active since 1934), and Warner River at Davisville, (period of record from 1940 to 1978 and 1999 to the present). At the Merrimack River at Goffs Falls in Manchester, NH, the May 2006 peak discharge of $74,700 \mathrm{ft}^{3} / \mathrm{s}$ was exceeded only by the historical floods of 1936 and 1938. Peak discharges equaled or exceeded a 100 -year recurrence interval at 14 streamgages and equaled or exceeded a 50-year recurrence interval at 22 streamgages. The most severe flooding was in Rockingham, Strafford, Merrimack, and eastern and northern Hillsborough Counties.

\section{Acknowledgments}

The author would like to thank Steve Doyon from NHDES for providing peak-stage and peak-discharge data from the streamgages that NHDES operates. Thanks also go to Curtis Crow, Kerrie Hartshorn and other staff from the New Hampshire Department of Transportation's (NHDOT) Survey Unit for providing elevation control point data and setting temporary elevation reference marks near select streamgages. Finally, the author would like to express appreciation to USGS staff: Kenneth Toppin, Chandlee Keirstead, Heather Sirotnak, Jeffrey Grey, Robert Flynn, Glenn Berwick, Richard Kiah, and Sanborn Ward-who assisted with collection and analysis of the data in this report, and Gregory Stewart and Robert Flynn — who provided technical reviews of this investigation.

\section{Selected References}

Benson, M.A., and Dalrymple, Tate, 1967, General field and office procedures for indirect discharge measurements: U.S. Geological Survey Techniques of Water-Resources Investigations, book 3, chap. A1, $30 \mathrm{p}$.

Federal Emergency Management Agency, 1977, Flood-insurance study, Town of Henniker, Merrimack County, New Hampshire: Washington, DC, $15 \mathrm{p}$.
Federal Emergency Management Agency, 1978a, Floodinsurance study, Town of Chichester, Merrimack County, New Hampshire: Washington, DC, 15 p.

Federal Emergency Management Agency, 1978b, Floodinsurance study, Town of Goffstown, Hillsborough County, New Hampshire: Washington, DC, 18 p.

Federal Emergency Management Agency, 1978c, Floodinsurance study, Town of Hillsborough, Hillsborough County, New Hampshire: Washington, DC, 20 p.

Federal Emergency Management Agency, 1979a, Floodinsurance study, City of Franklin, Merrimack County, New Hampshire: Washington, DC, 20 p.

Federal Emergency Management Agency, 1979b, Floodinsurance study, Town of Merrimack, Hillsborough County, New Hampshire: Washington, DC, 27 p.

Federal Emergency Management Agency, 1979c, Floodinsurance study, Town of Pelham, Hillsborough County, New Hampshire: Washington, DC, 22 p.

Federal Emergency Management Agency, 1979d, Floodinsurance study, Town of Peterborough, Hillsborough County, New Hampshire: Washington, DC, 21 p.

Federal Emergency Management Agency, 1980a, Floodinsurance study, City of Laconia, Belknap County, New Hampshire: Washington, DC, 24 p.

Federal Emergency Management Agency, 1980b, Floodinsurance study, City of Manchester, Hillsborough County, New Hampshire: Washington, DC, 24 p.

Federal Emergency Management Agency, 1980c, Floodinsurance study, Town of Antrim, Hillsborough County, New Hampshire: Washington, DC, 20 p.

Federal Emergency Management Agency, 1982, Floodinsurance study, Town of Rumney, Grafton County, New Hampshire: Washington, DC, 15 p.

Federal Emergency Management Agency, 1987, Floodinsurance study, Town of Warner, Merrimack County, New Hampshire: Washington, DC, 18 p.

Federal Emergency Management Agency, 1988a, Floodinsurance study, Town of Canaan, Grafton County, New Hampshire: Washington, DC, 23 p.

Federal Emergency Management Agency, 1988b, Floodinsurance study, Town of Hopkinton, Merrimack County, New Hampshire: Washington, DC, 16 p.

Federal Emergency Management Agency, 1990a, Floodinsurance study, Town of Haverhill, Grafton County, New Hampshire: Washington, DC, 10 p. 
Federal Emergency Management Agency, 1990b, Floodinsurance study, Town of Lebanon, Grafton County, New Hampshire: Washington, DC, 16 p.

Federal Emergency Management Agency, 1991, Floodinsurance study, Town of Tamworth, Carroll County, New Hampshire: Washington, DC, 12 p.

Federal Emergency Management Agency, 1993a, Floodinsurance study, Town of Weare, Hillsborough County, New Hampshire: Washington, DC, 16 p.

Federal Emergency Management Agency, 1993b, Floodinsurance study, Town of Webster, Merrimack County, New Hampshire: Washington, DC, 10 p.

Federal Emergency Management Agency, 1997, Floodinsurance study, Town of Tilton, Belknap County, New Hampshire: Washington, DC, 20 p.

Federal Emergency Management Agency, 1999, Floodinsurance study, City of Concord, Merrimack County, New Hampshire: Washington, DC, 20 p.

Federal Emergency Management Agency, 2000a, Floodinsurance study, Town of Lincoln, Grafton County, New Hampshire: Washington, DC, 11 p.

Federal Emergency Management Agency, 2000b, Floodinsurance study, Town of Woodstock, Grafton County, New Hampshire: Washington, DC, 15 p.

Federal Emergency Management Agency, 2001a, Floodinsurance study, Town of New Boston, Hillsborough County, New Hampshire: Washington, DC, 18 p.

Federal Emergency Management Agency, 2001b, Floodinsurance study, Town of Plymouth, Grafton County, New Hampshire: Washington, DC, 18 p.

Federal Emergency Management Agency, 2002, Floodinsurance study, Town of Conway, Carroll County, New Hampshire: Washington, DC, 21 p.

Federal Emergency Management Agency, 2005a, Floodinsurance study, Rockingham County, New Hampshire, all jurisdictions: Washington, DC, $87 \mathrm{p}$.

Federal Emergency Management Agency, 2005b, Floodinsurance study, Strafford County, New Hampshire, all jurisdictions: Washington, DC, $41 \mathrm{p}$.

LeBlanc, D.R., 1978, Progress report on hydrologic investigations of small drainage areas in New HampshirePreliminary relations for estimating peak discharge on rural, unregulated streams: U.S. Geological Survey WaterResources Investigations 78-47, 9 p.
Matthai, H.F., 1967, Measurement of peak discharge at width contractions by indirect methods: U.S. Geological Survey Techniques of Water-Resources Investigations, book 3, chap. A4, 44 p.

National Oceanic and Atmospheric Administration, 1996, Climatological data-New England, October 1996:

Climatological Data, v. 108, no. 10, 46 p.

National Oceanic and Atmospheric Administration, 2006a, Record of climatological observations (COOP), accessed November 17, 2006, at http://www7.ncdc.noaa.gov/IPSA coopgetpublications.htm.

National Oceanic and Atmospheric Administration, 2006b, Public information statement, accessed November 2, 1996, at http://www.ncdc.noaa.gov/oa/climate/research/2006/may/ boxpns.txd.

National Oceanic and Atmospheric Administration, 2006c, Climate of 2006-May in historical perspective, accessed November 2, 2006, at http://www.ncdc.noaa.gov/oa/climate, research/2006/may/may06.htm

Northeast Regional Climate Center, 2006, Monthly and seasonal climate summary tables, accessed November 2, 2006, at http://met-www.cit.cornell.edu/climate/climate_summary. htm.

Northeast River Forecast Center, 2006, 7-day observed precipitation_valid May 18, 2006, 1200 UTC, accessed November 7, 2006, at http://www.ncdc.noaa.gov/imgd climate/research/2006/may/ne-rainfall.git.

U.S. Army Corps of Engineers, 2006a, HEC-RAS river analysis system, version 3.1.3: Hydrologic Engineering Center, accessed November 2, 2006, at http://www.hec.usace.army. mil.

U.S. Army Corps of Engineers, 2006b, New England District Corps of Engineers reservoir regulation team, accessed November 8, 2006, at http://www.nae.usace.army.mil].

U.S. Geological Survey, 2006a, Water resources application software, PeakFQ, accessed November 6, 2006, at http://water.usgs.gov/software/peakfq.htm.

U.S. Geological Survey, 2006b, Peak streamflow for New Hampshire: National Water Information System, accessed November 6, 2006, at http://nwis.waterdata.usgs. gov/nh/nwis/peak.

U.S. Interagency Advisory Committee on Water Data, 1982, Guidelines for determining flood flow frequency, Bulletin 17-B of the Hydrology Subcommittee: Reston, VA, U.S. Geological Survey, Office of Water Data Coordination, $183 \mathrm{p}$. 


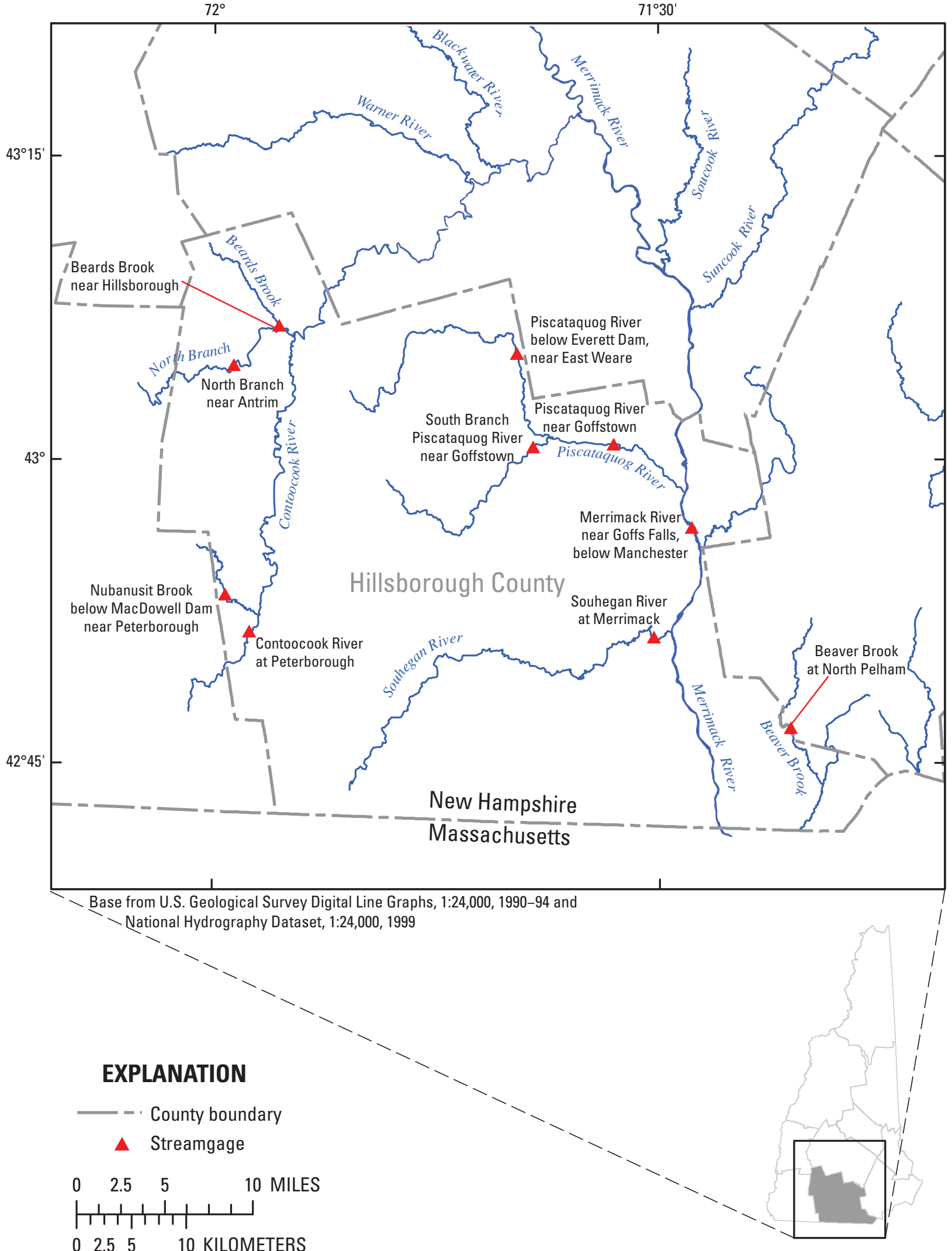

Figure 2A. Location of streamgages having peak stage and discharge data for the May 2006 flooding in Hillsborough County, New Hampshire. 


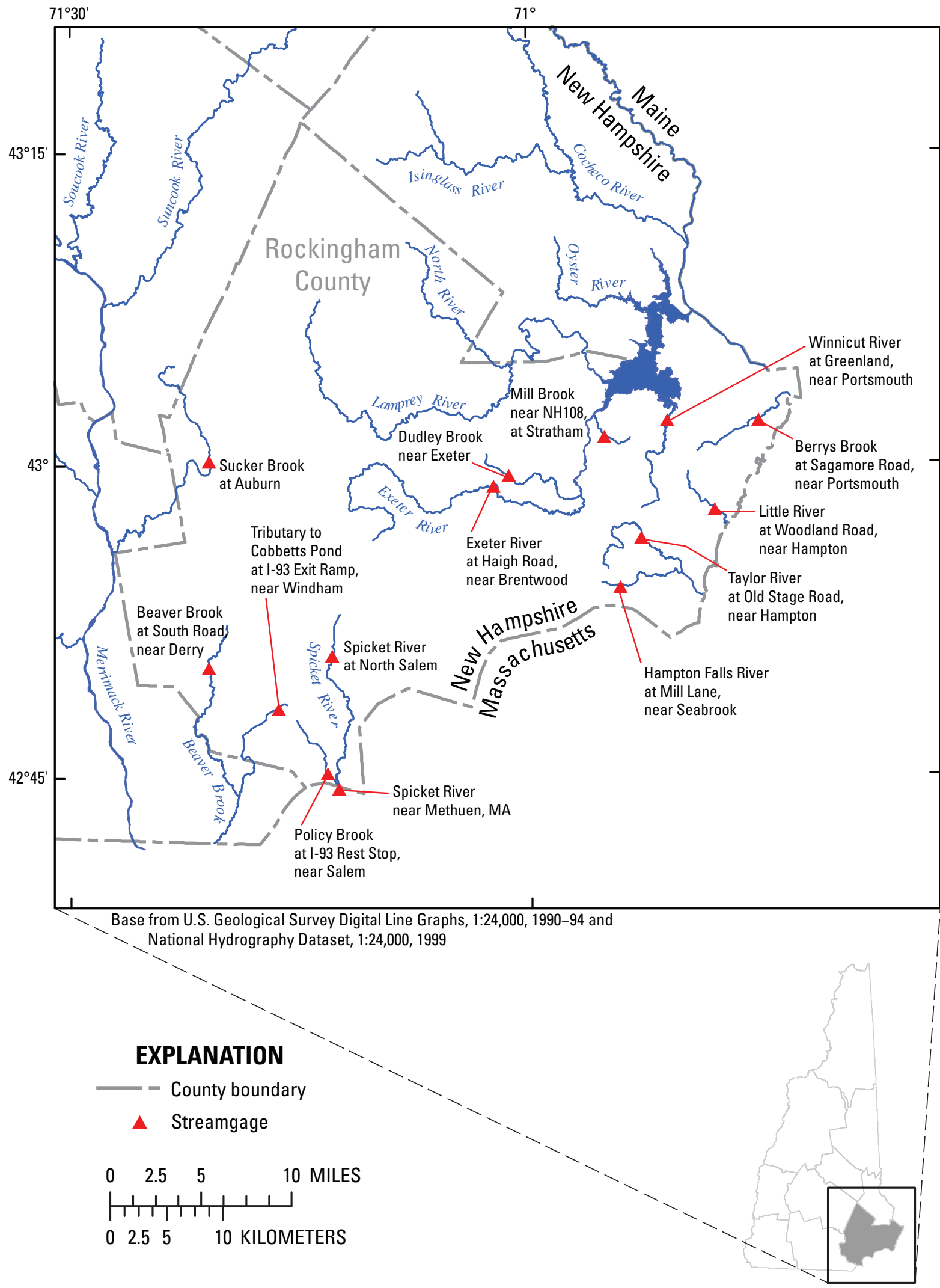

Figure 2B. Location of streamgages having peak stage and discharge data for the May 2006 flooding in Rockingham County, New Hampshire. 


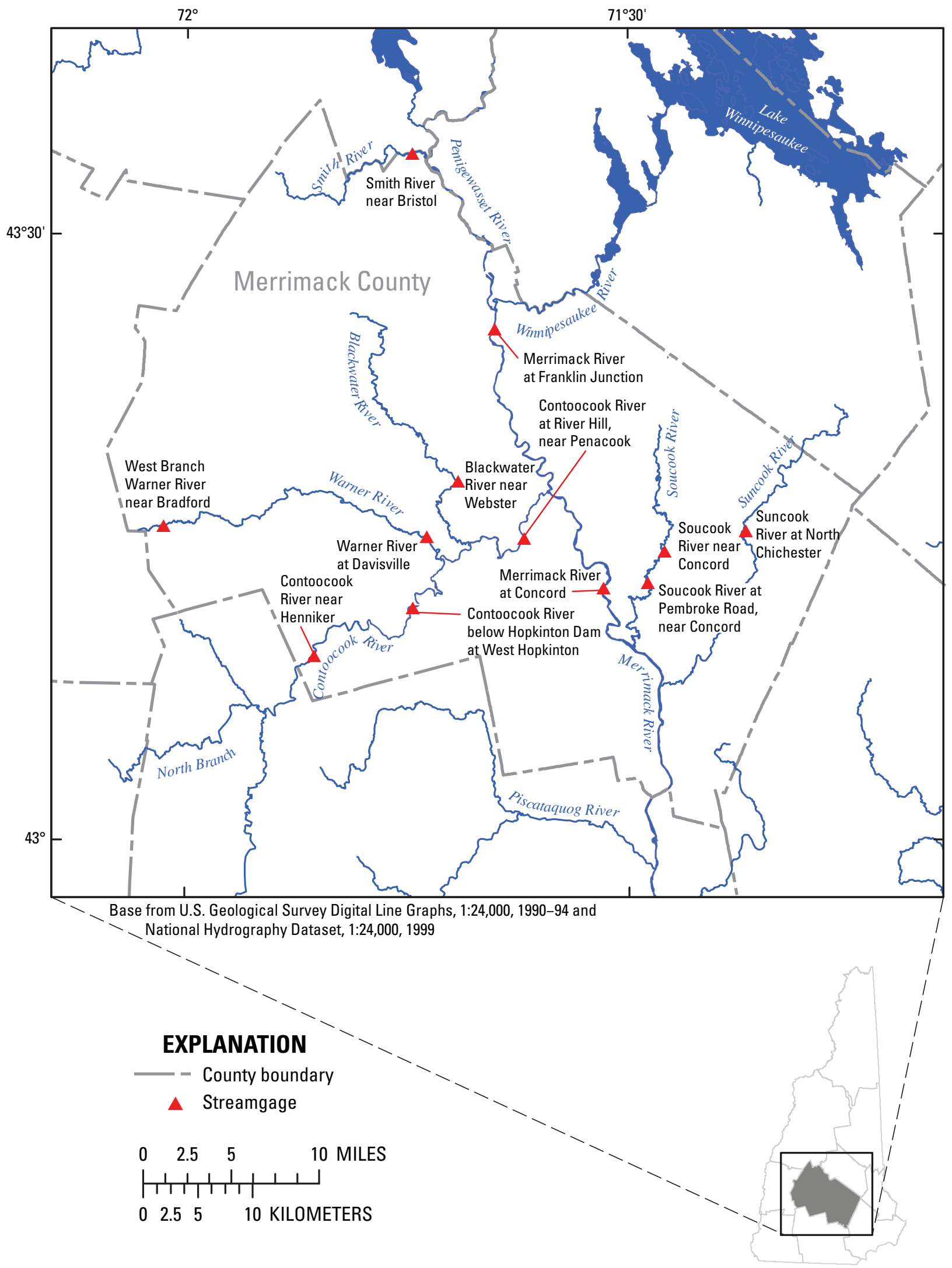

Figure 2C. Location of streamgages having peak stage and discharge data for the May 2006 flooding in Merrimack County, New Hampshire. 


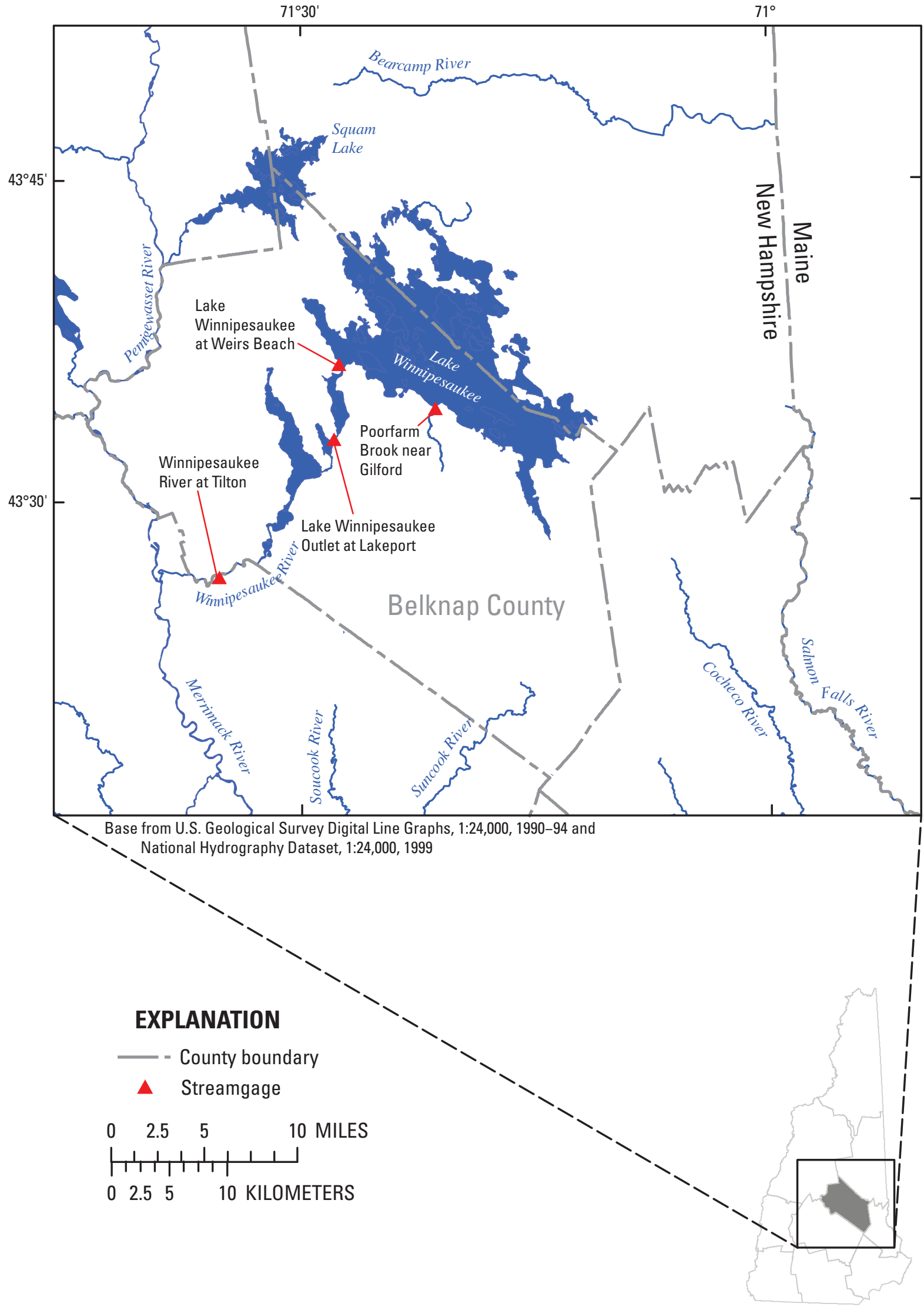

Figure 2D. Location of streamgages having peak stage and discharge data for the May 2006 flooding in Belknap County, New Hampshire. 


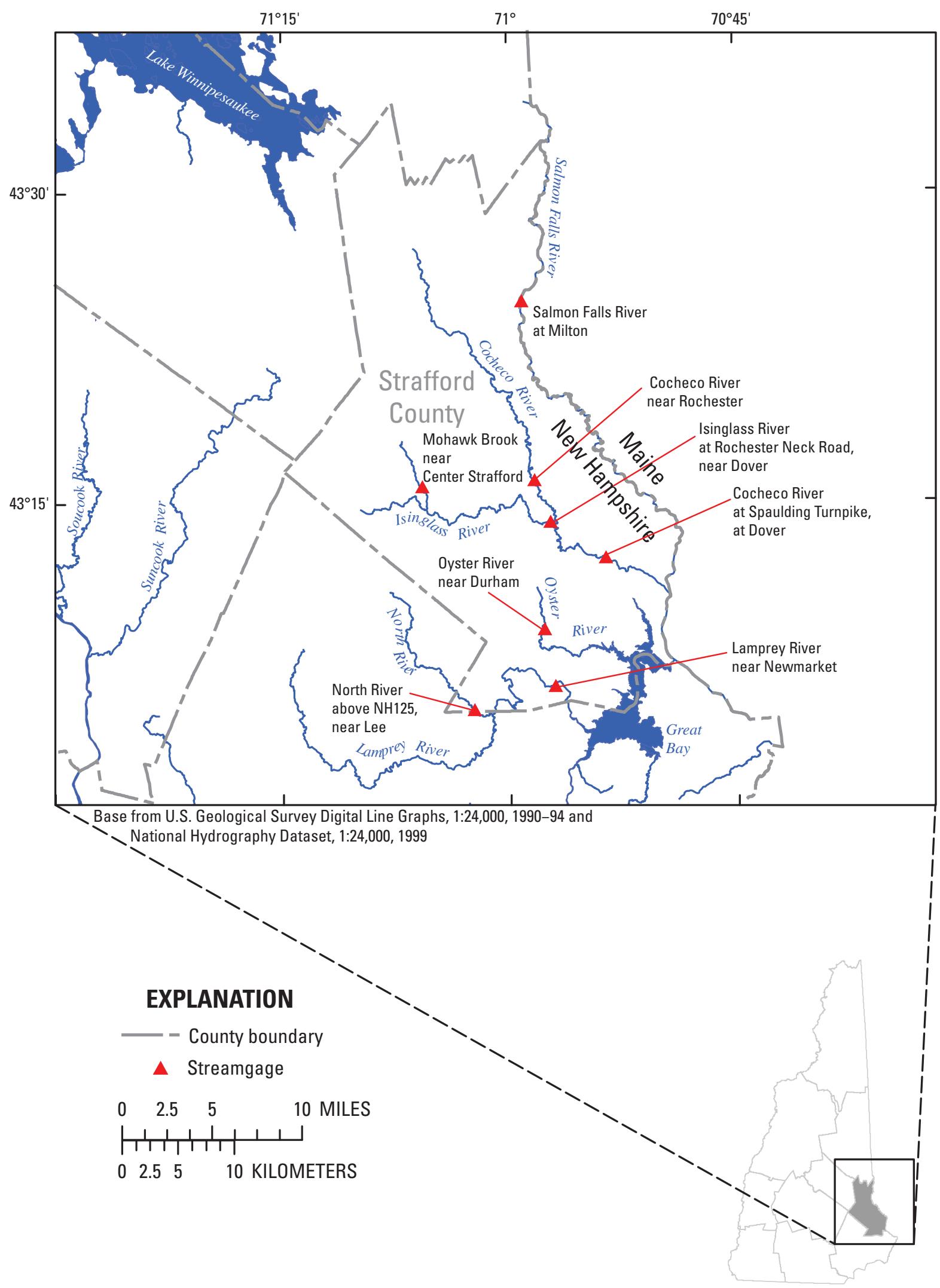

Figure 2E. Location of streamgages having peak stage and discharge data for the May 2006 flooding in Strafford County, New Hampshire. 


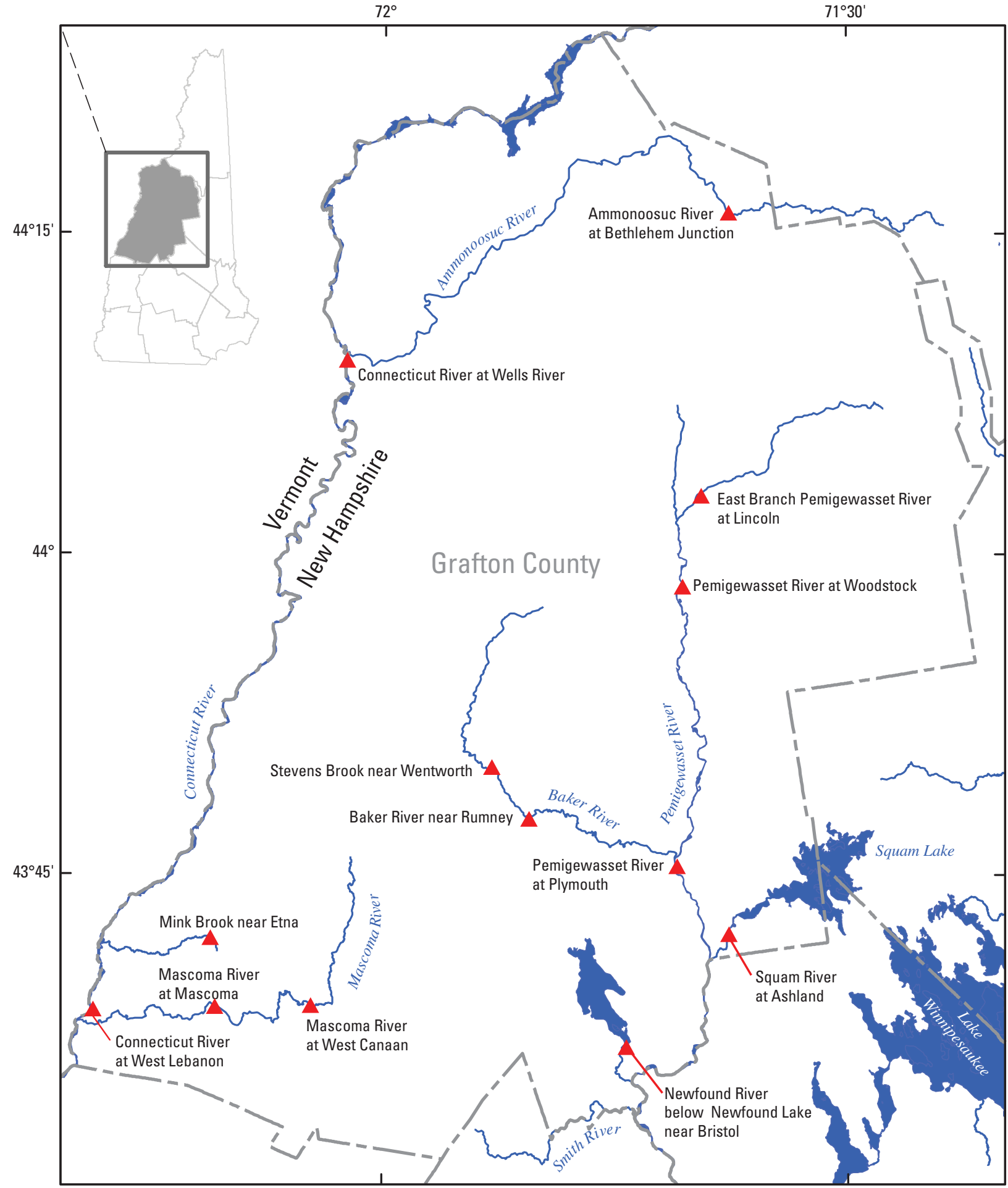

Base from U.S. Geological Survey Digital Line Graphs, 1:24,000, 1990-94 and National Hydrography Dataset, 1:24,000, 1999

\section{EXPLANATION}

\section{- County boundary}

- Streamgage

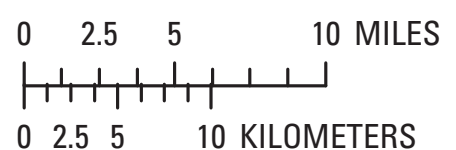

Figure 2F. Location of streamgages having peak stage and discharge data for the May 2006 flooding in Grafton County, New Hampshire. 


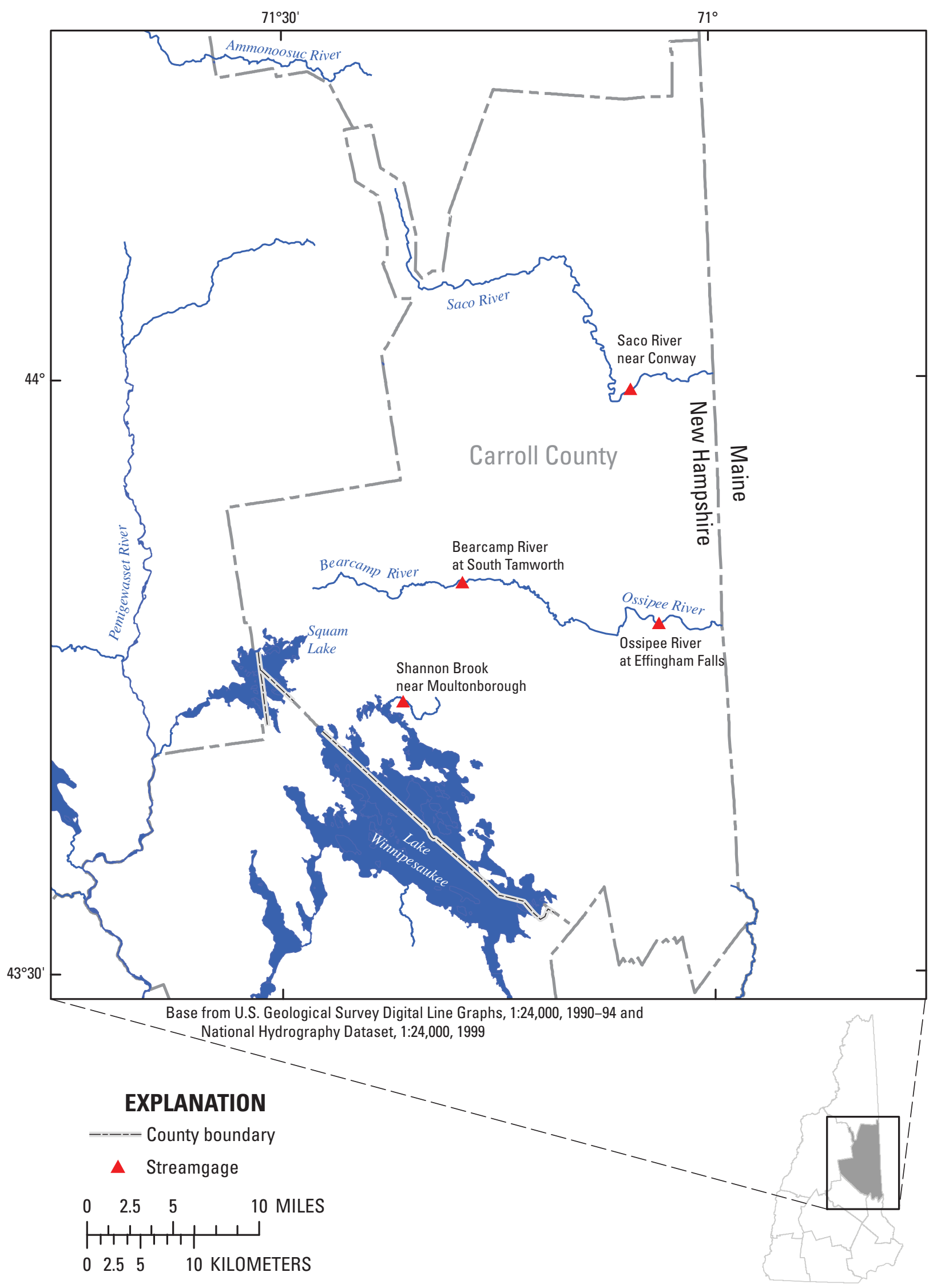

Figure 2G. Location of streamgages having peak stage and discharge data for the May 2006 flooding in Carroll County, New Hampshire. 
Tables 1-4 


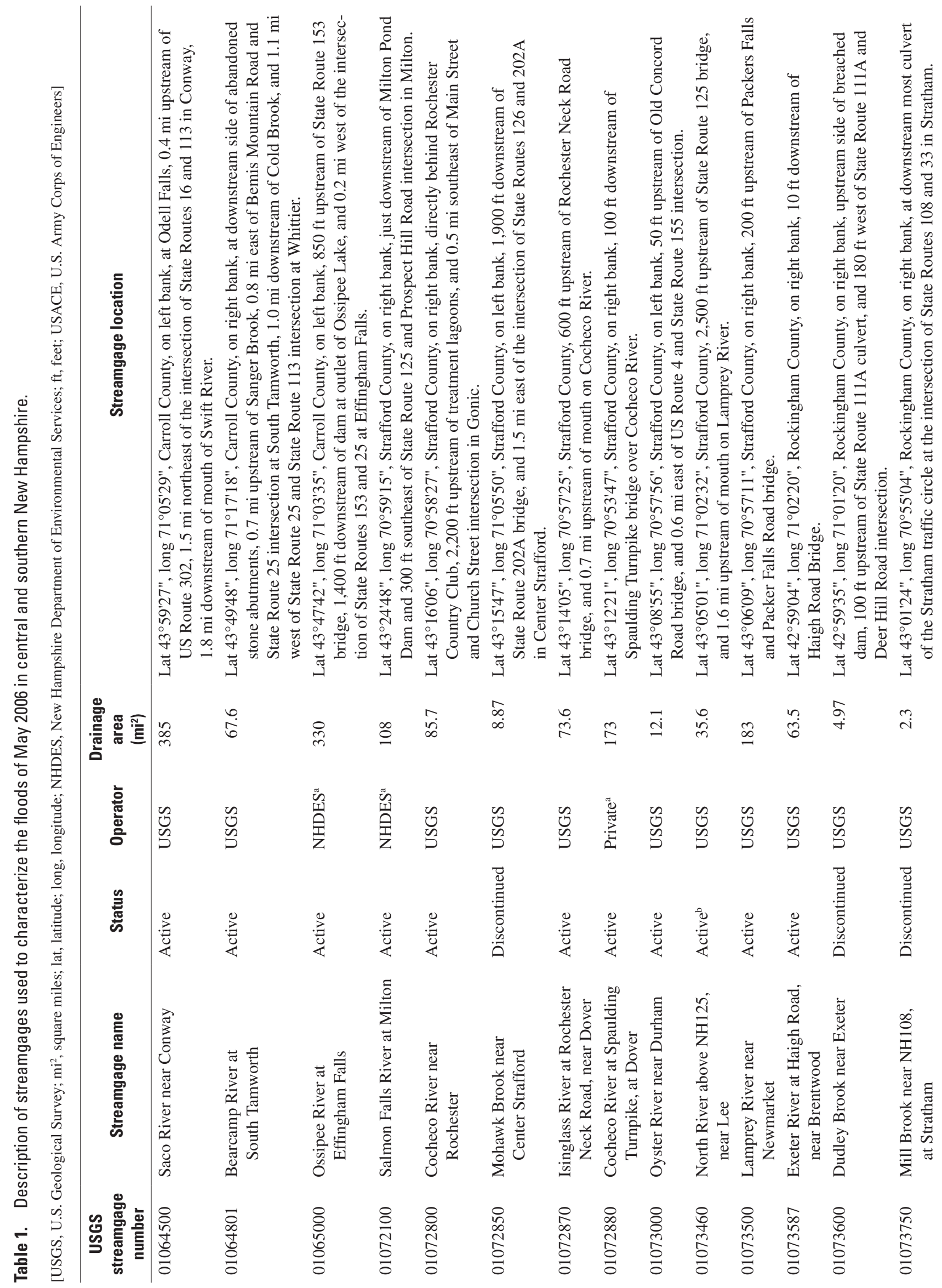




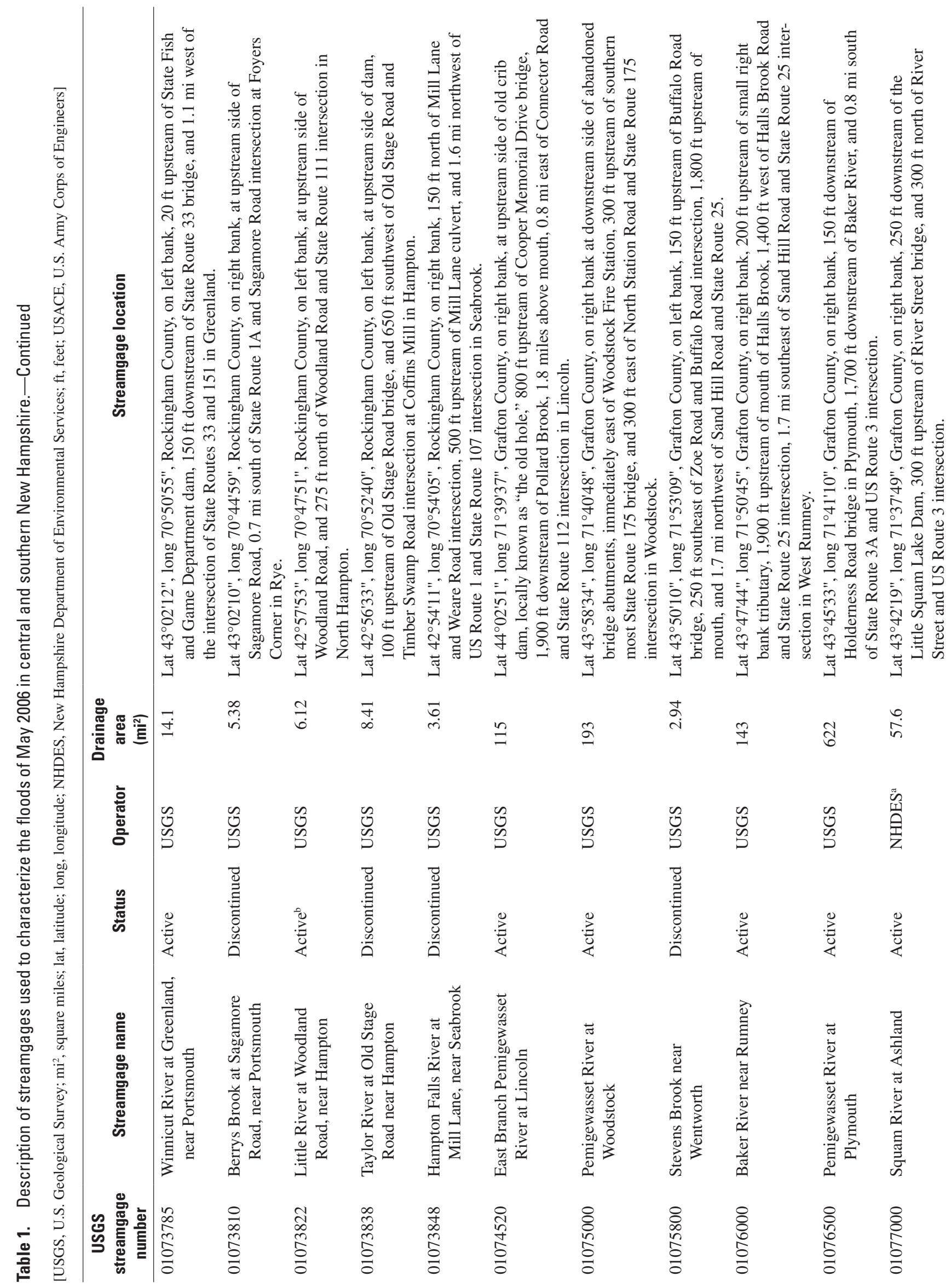




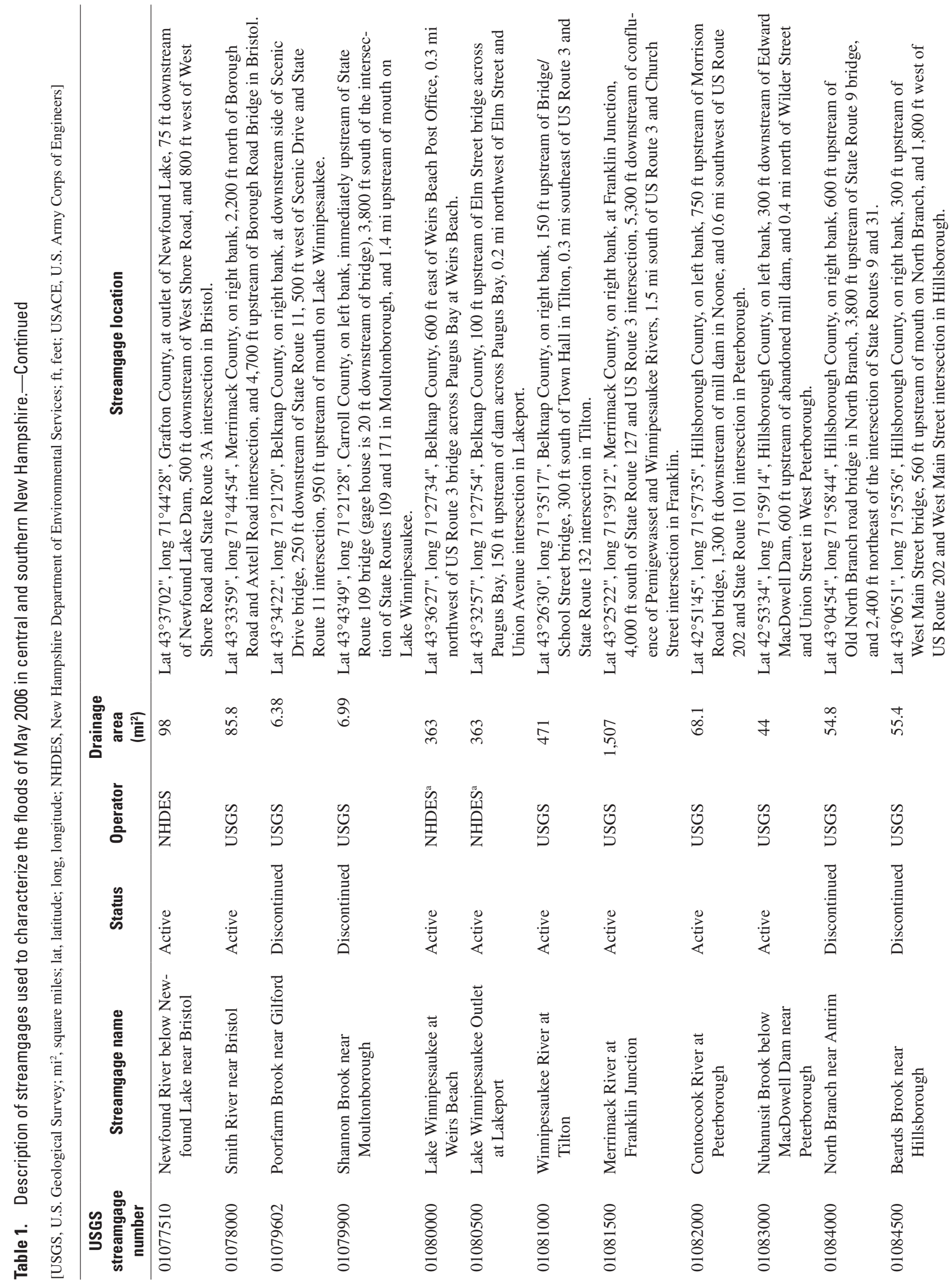




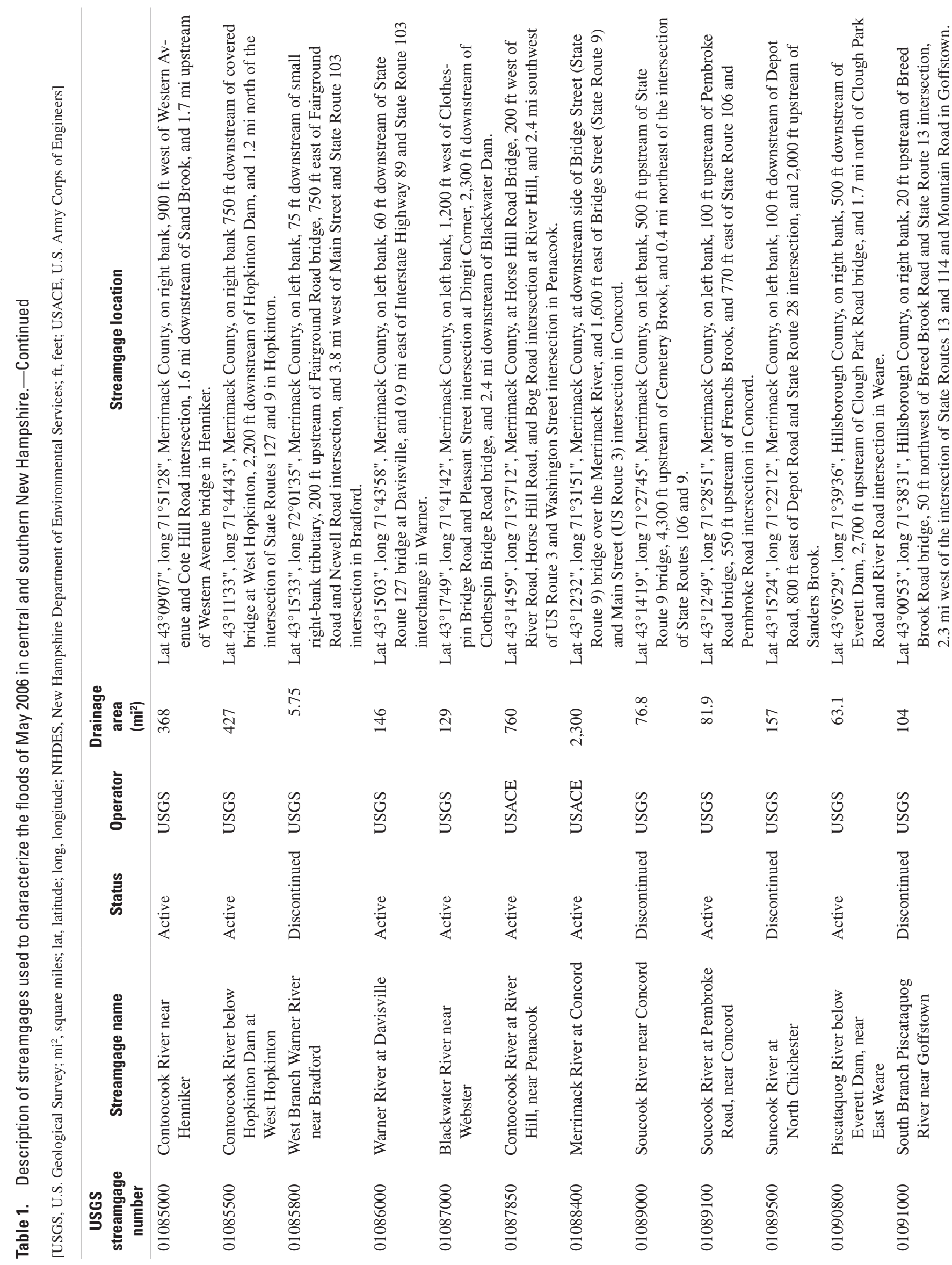




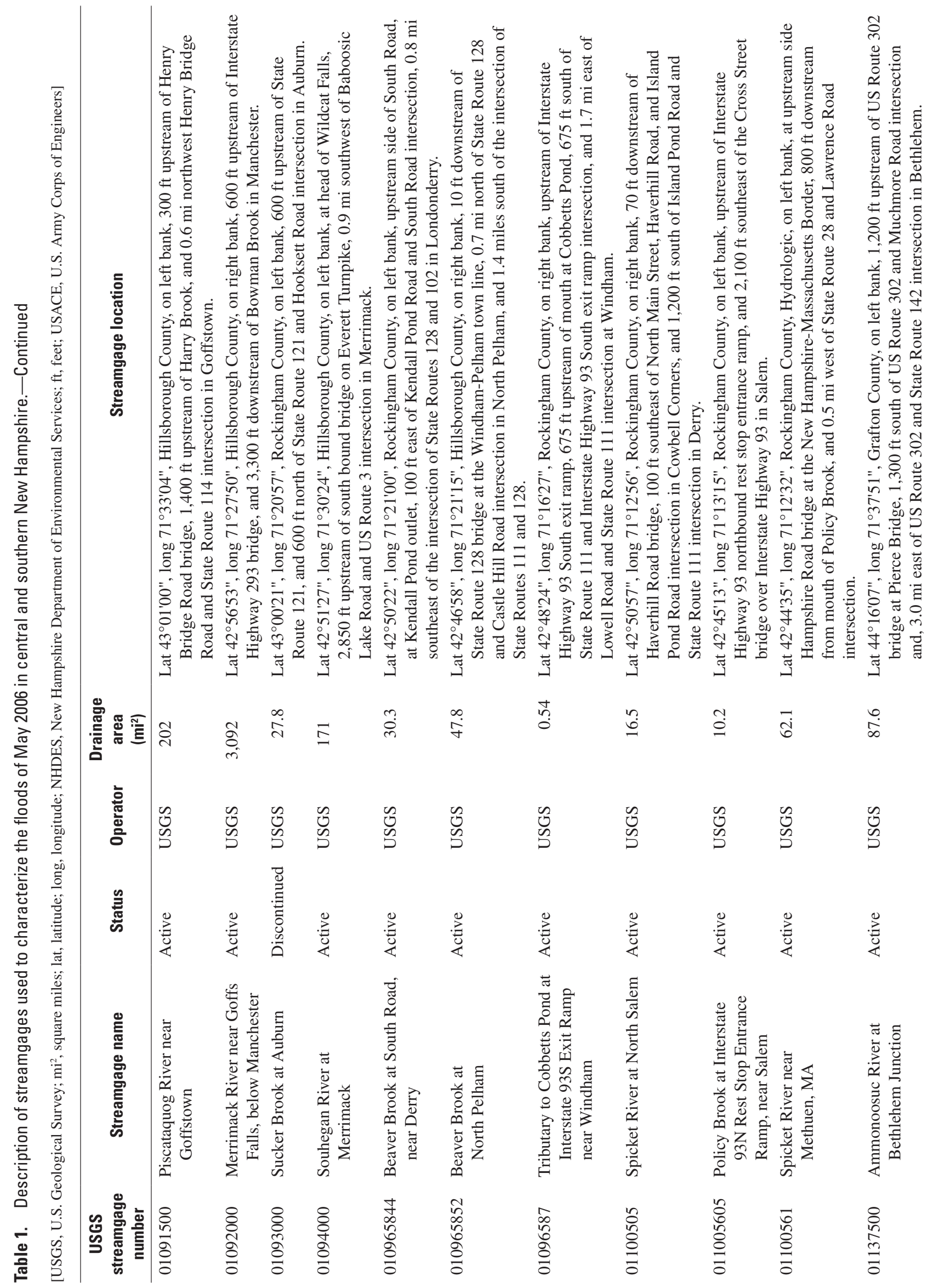




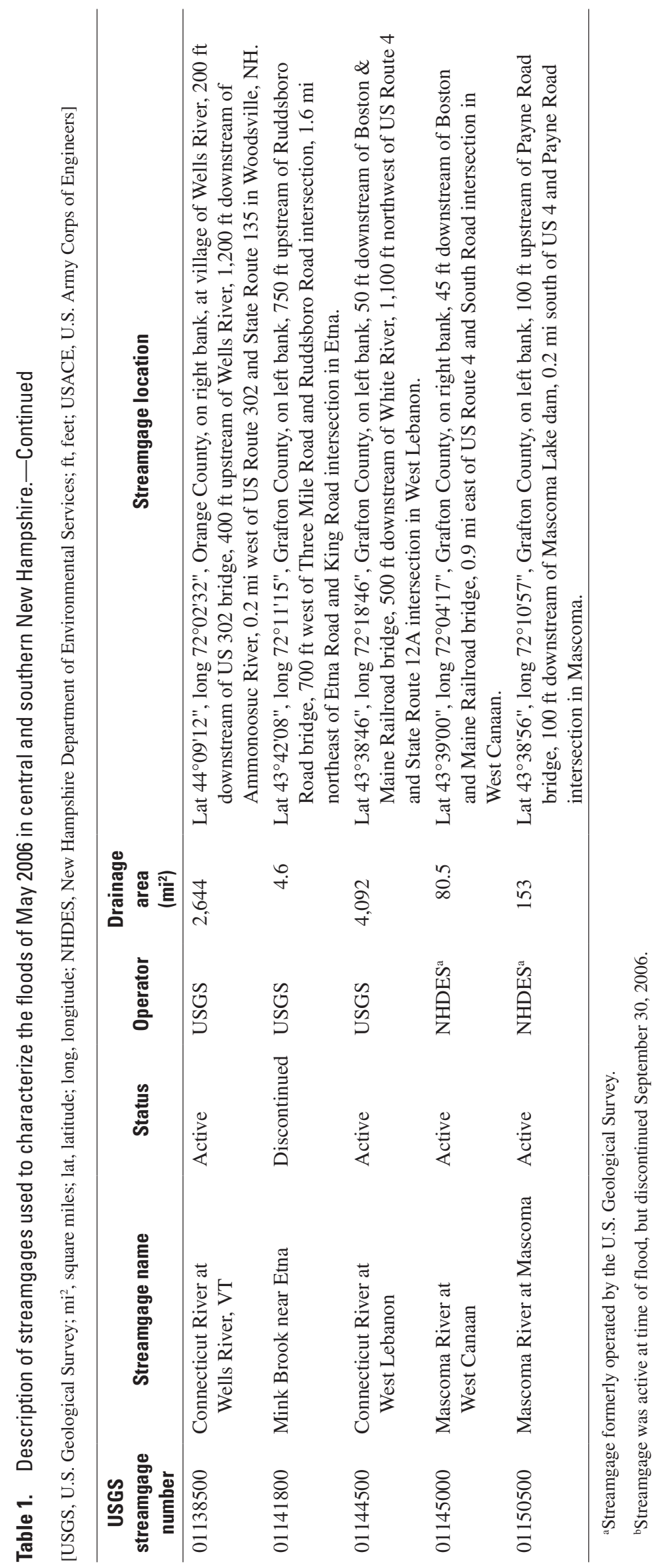




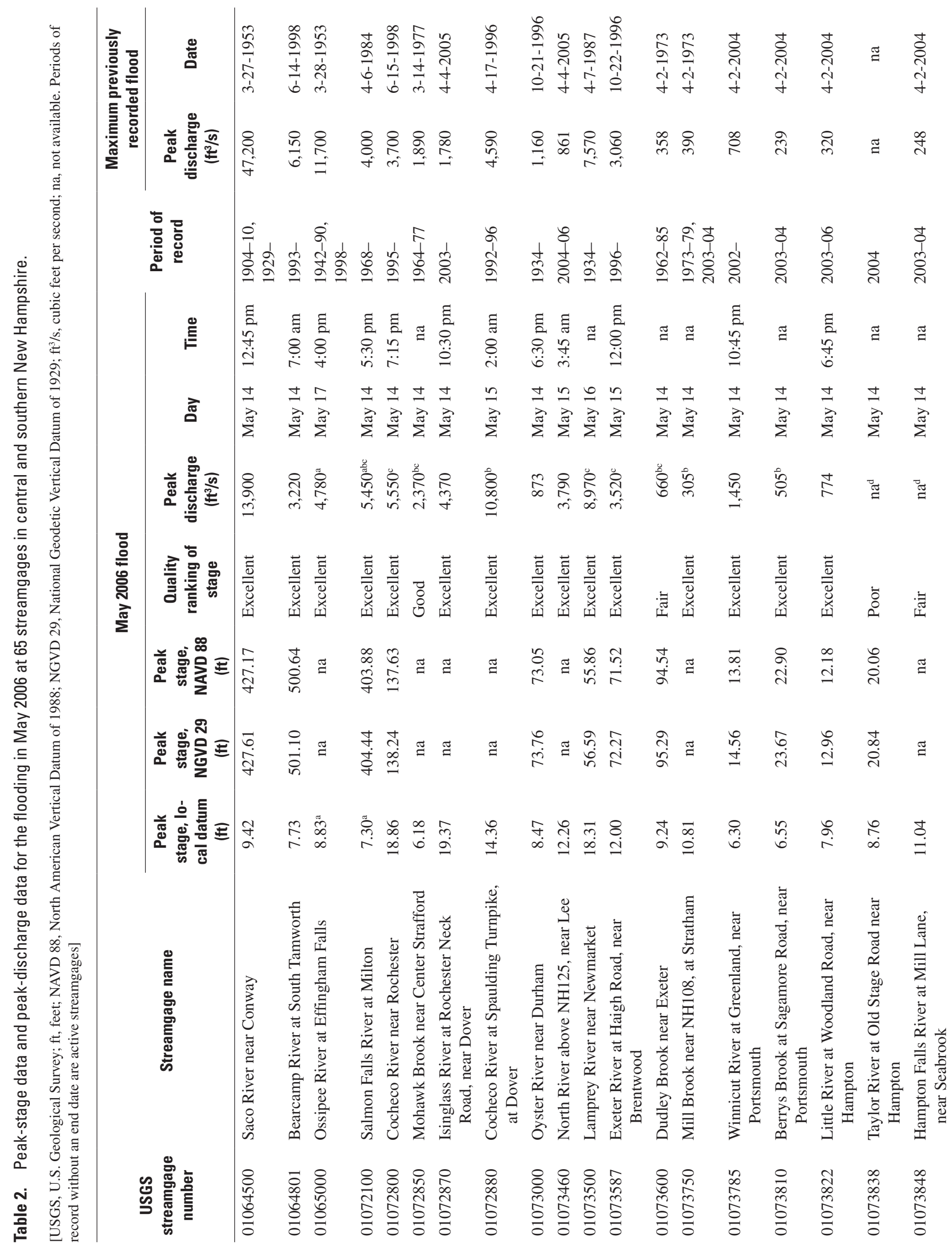




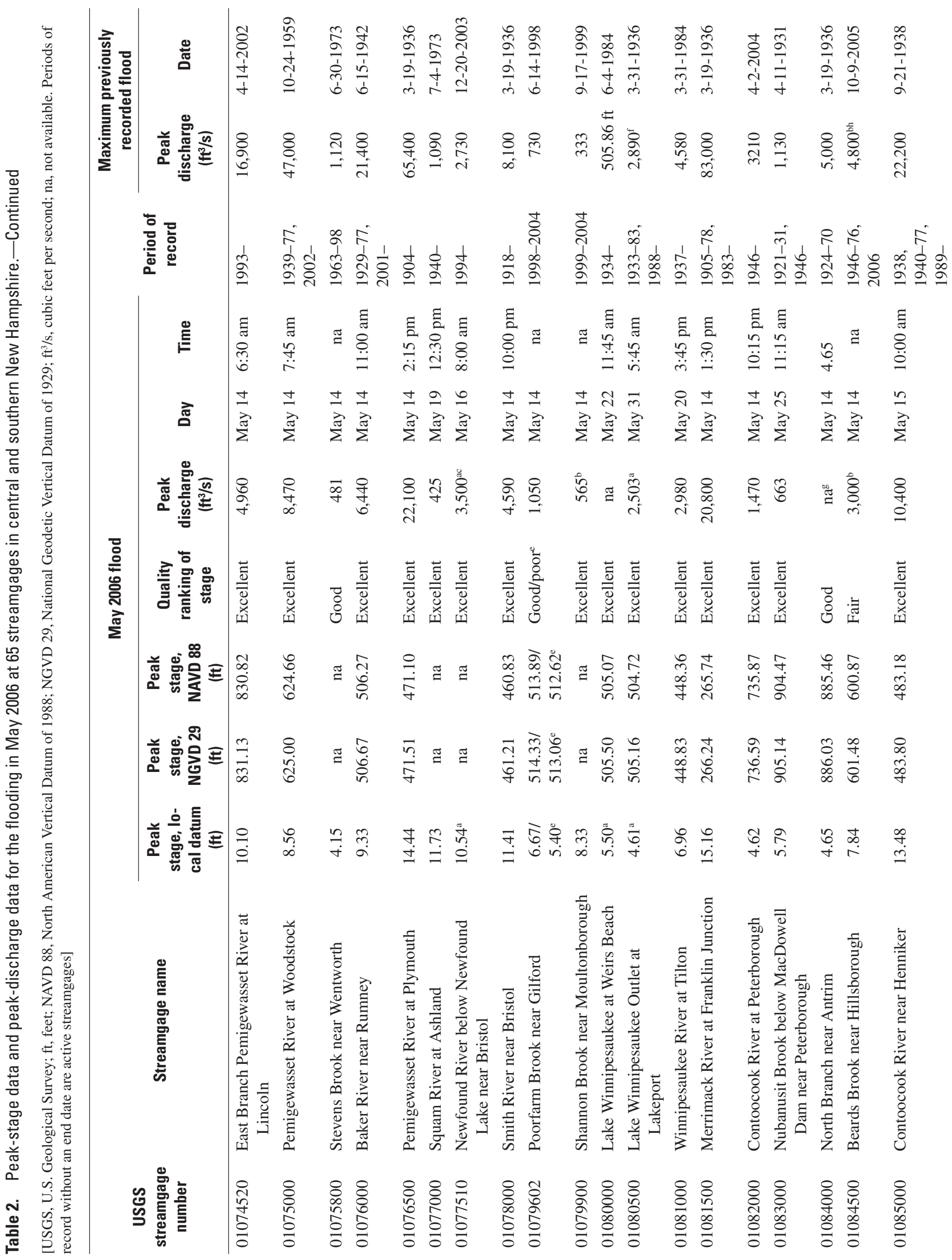




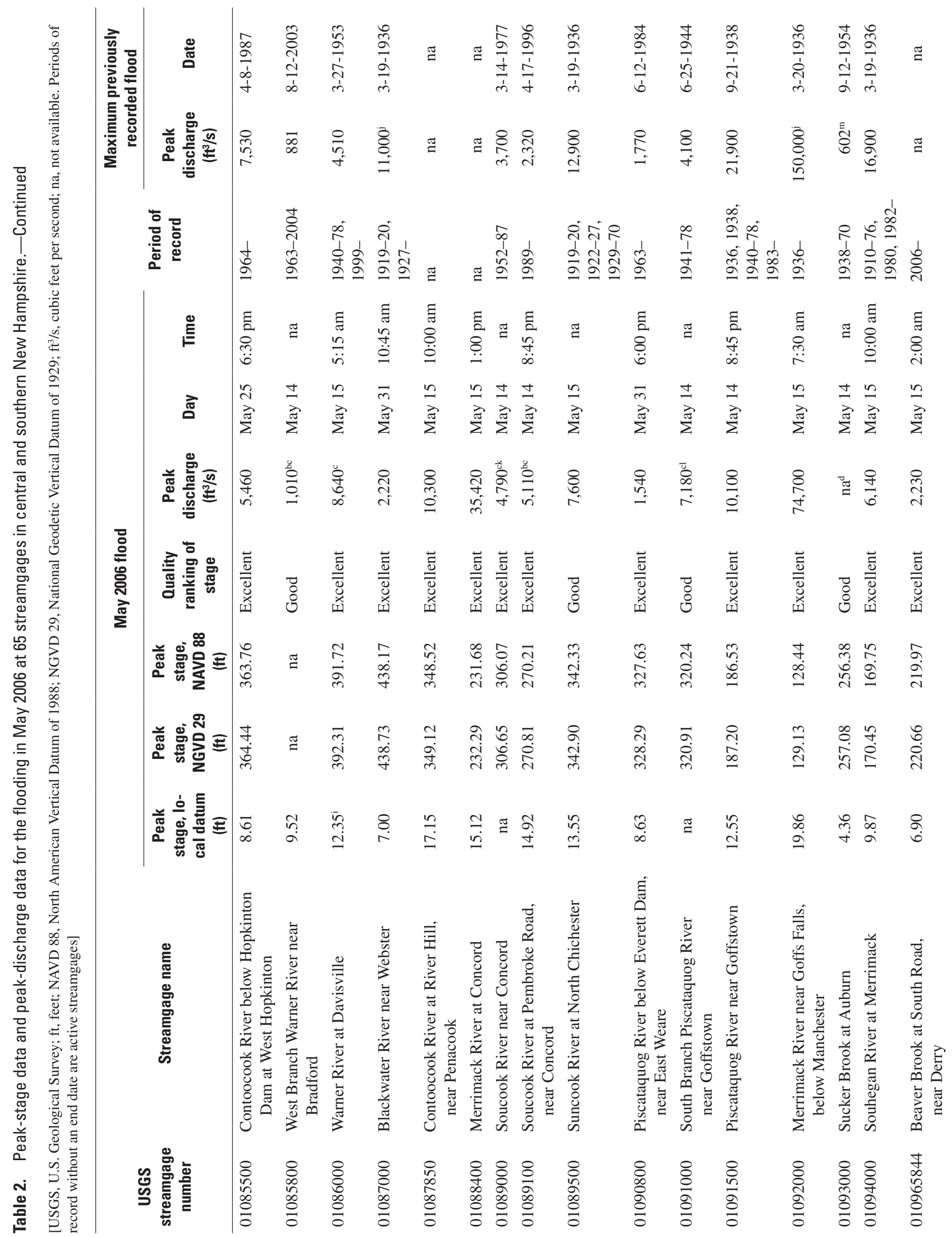




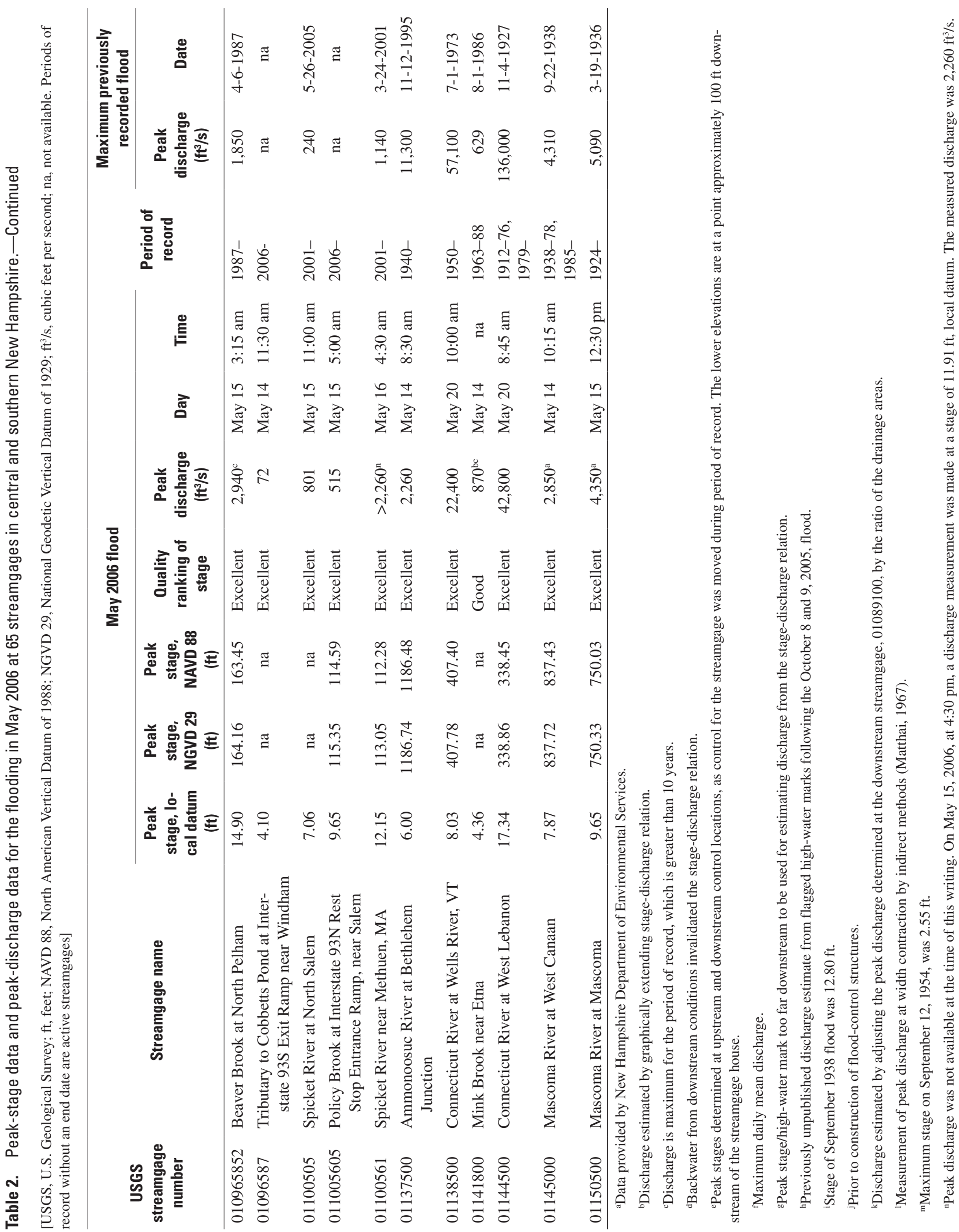




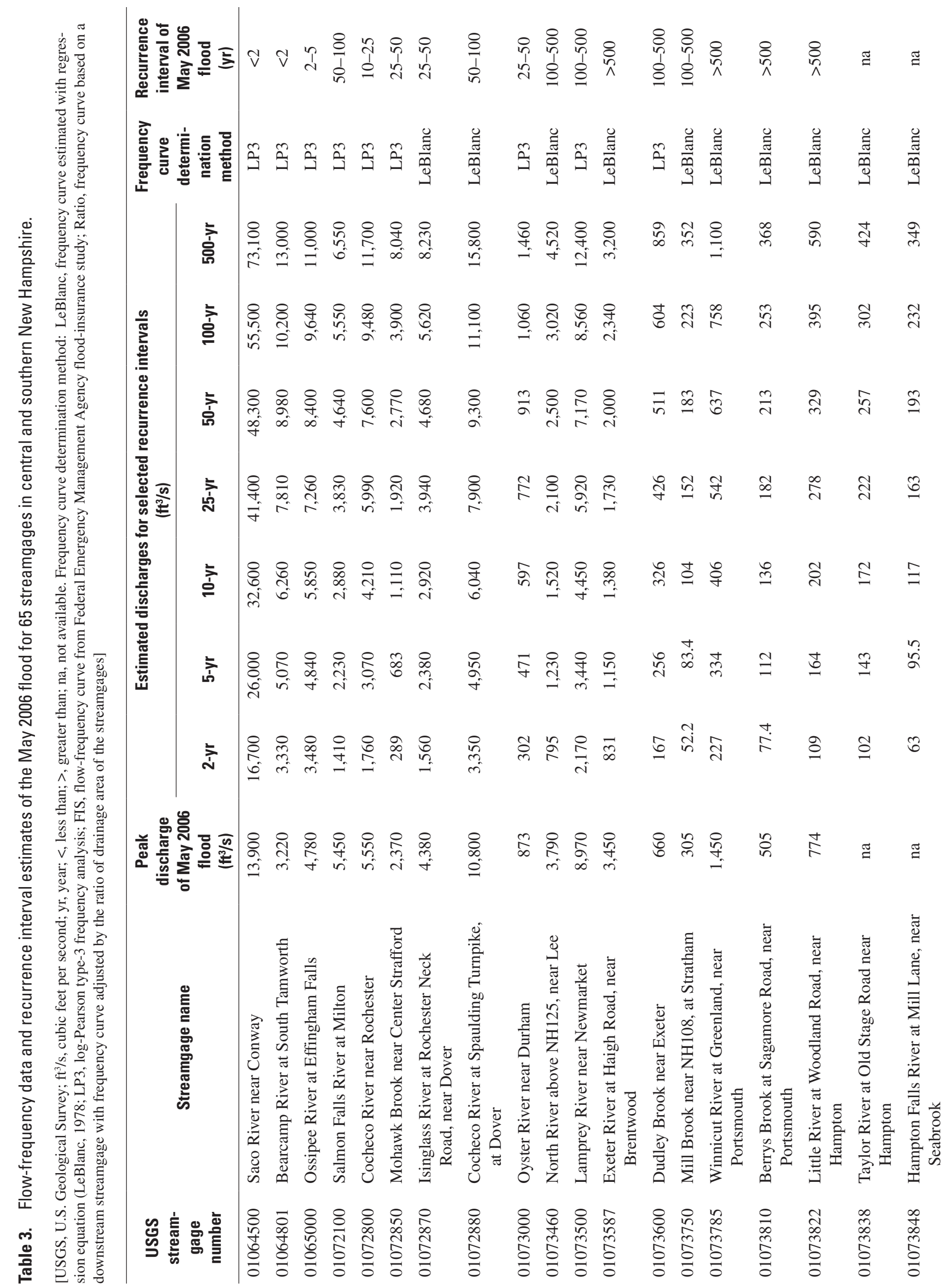




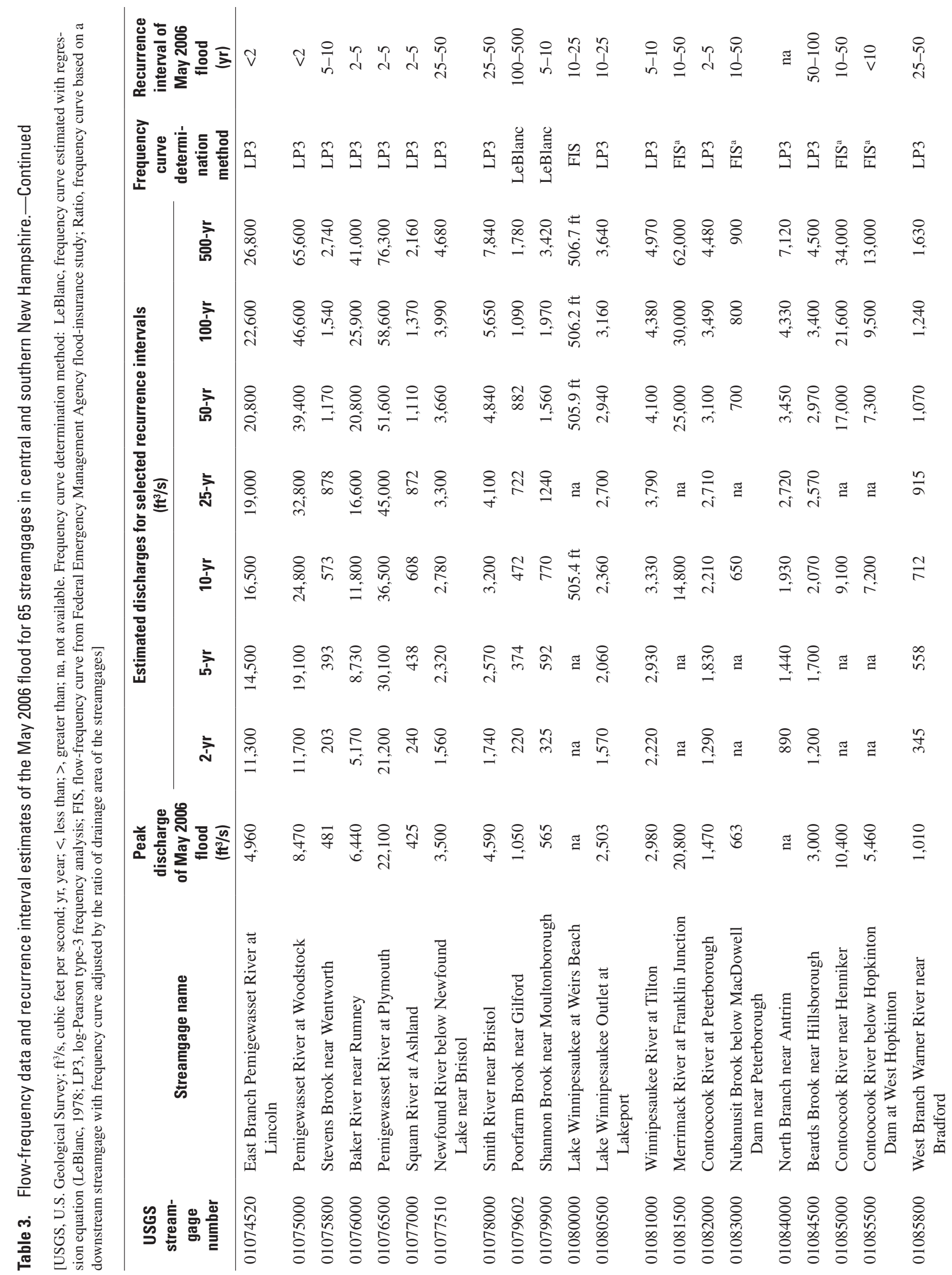




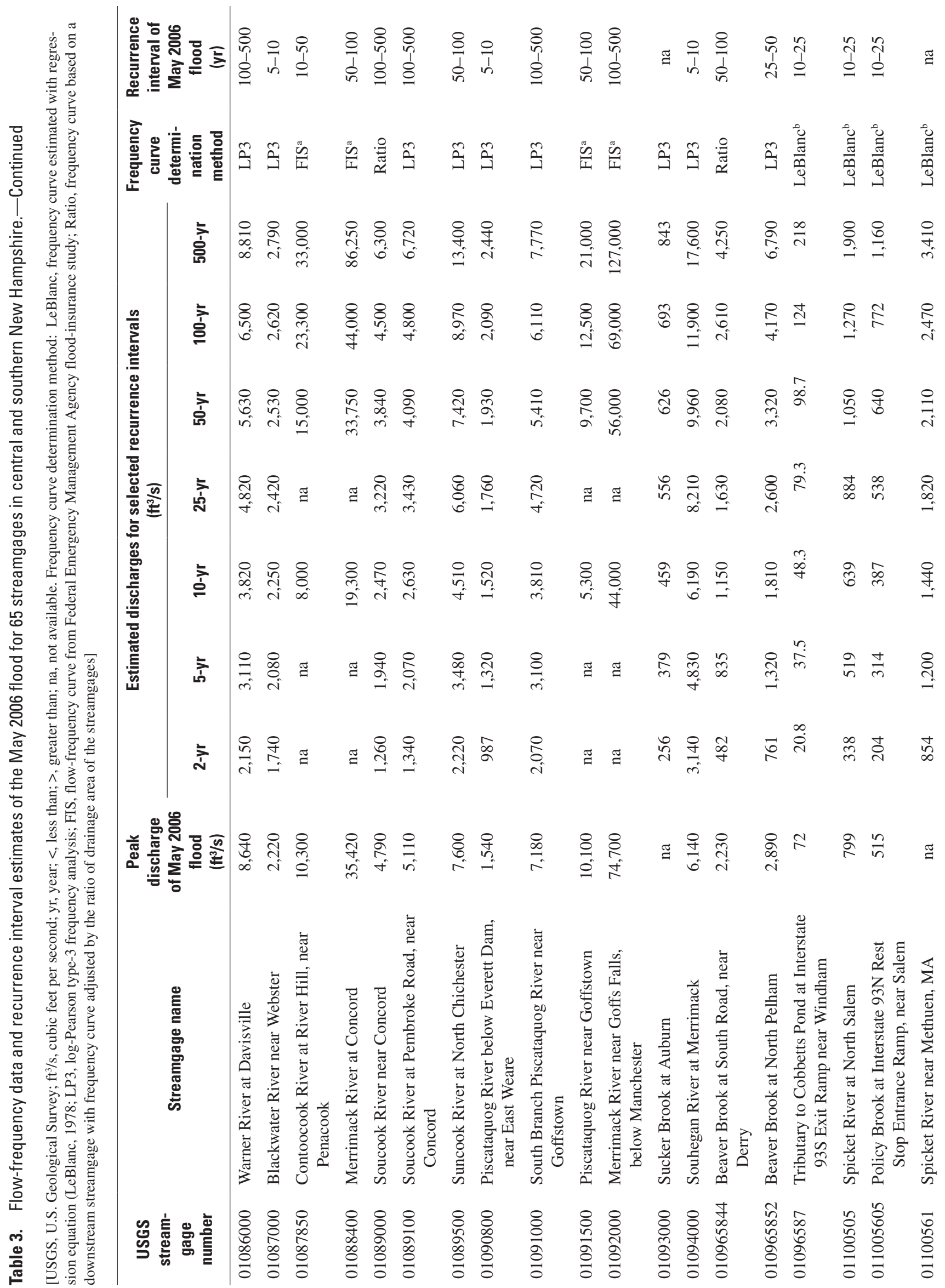




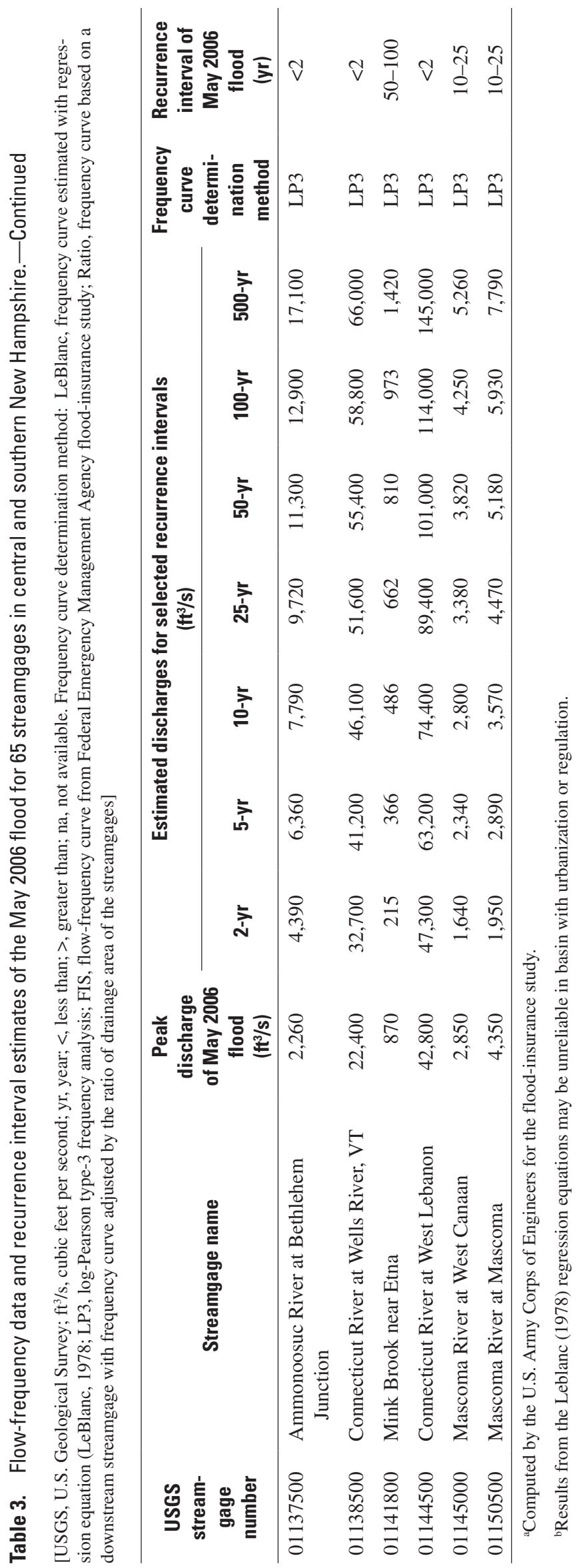




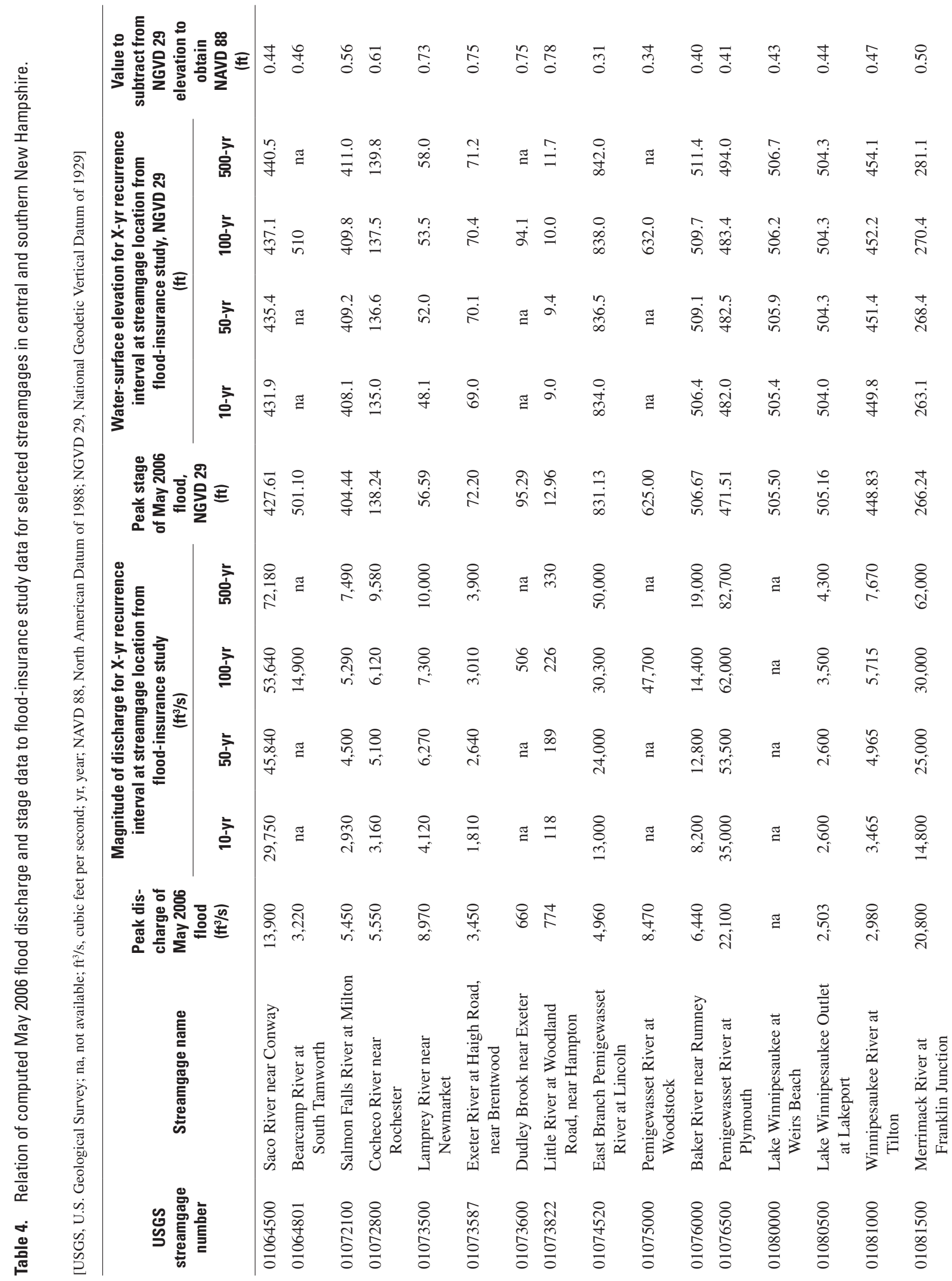




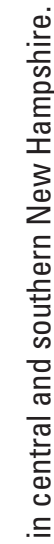

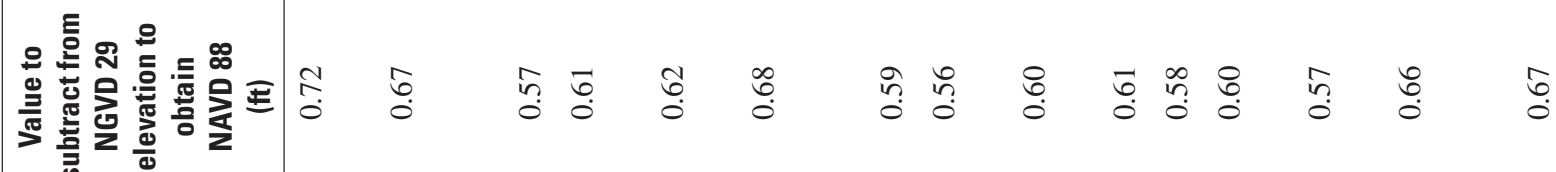

d

ठ্

惫

के

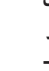

咅

.

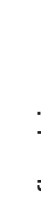




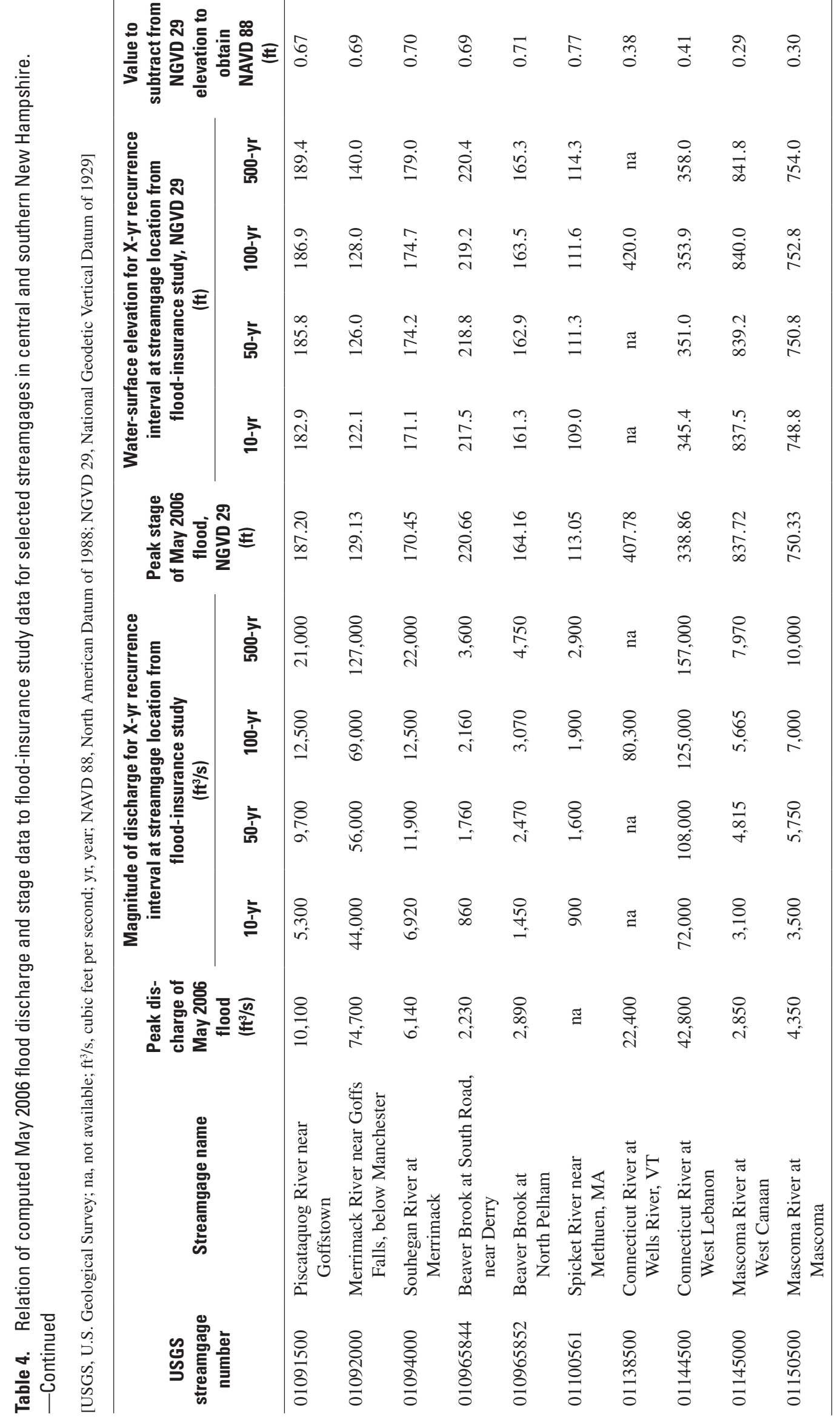


Prepared by Publications Service Center 1

For more information concerning the research in this report, contact:

Keith W. Robinson, Director

U.S. Geological Survey

New Hampshire-Vermont Water Science Center

361 Commerce Way

Pembroke, NH 03275

or visit our Web site at:

http://nh.water.usgs.gov 


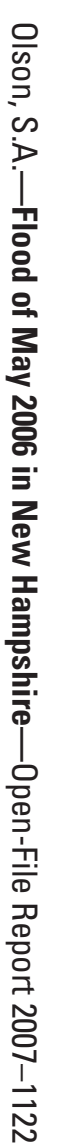

8 Printed on recycled paper 